\title{
Meaning and Captivity in Classical Arabic Philology
}

\author{
David Larsen \\ New York University, New York, NY, usA \\ david.larsen@nyu.edu
}

\begin{abstract}
This article takes a close look at the word $m a^{\prime} n \bar{a}$ as analyzed by Abbasid-era authorities on the Arabic language, chiefly Ibn Fāris (d. 395/1004). The word's context-sensitivity and polysemy are well known; less well appreciated are the lexical and morphological preconditions for ma'nā's diversity of meanings across the disciplines. Even less well studied (though widely quoted in lexicographical literature) is the anonymous basitmeter couplet that Ibn Fāris cites in al-Ṣạhibífı́fiqh al-lugha as a locus probans for the word. The speaker in these verses boasts of ransoming a bound captive ('anni) ), using ma'nā to refer to the captive's abject state. There is evidence to suggest that the verses once featured in a lost work of the philologist Abū Nașr al-Bāhilī (d. 231/855) called Kitāb Abyāt al-ma'ānī. This was an anthology of verses framed like riddles whose interpretation hinged on double meanings and rare metaphors, and its form and content may be judged by numerous outtakes preserved in later anthologies and lexica. The affiliation of Ibn Fāris's verses to Kitāb Abyāt al-ma'ānī would confirm that the derivation of ma'nā truly is a puzzle with multiple answers. To contemplate its parameters is to uncover a paradigm for meaning in which noetic intention and phenomenological exposure are figurative correlates of bodily captivity and duress.
\end{abstract}

\section{Keywords}

Abū Nașr al-Bāhilī - affect theory - Arabic lexicography - Ibn Fāris - mánā - semiotic theory 


\section{Introduction}

Attested meanings for the Arabic noun ma'nā are legion. ${ }^{1}$ In every field of Arabophone intellectual life, the word has been multiply applied. ${ }^{2}$ While the word's polysemy is well known, the lexical and linguistic preconditions for it are hardly anywhere discussed. To put it another way, modern scholars treat ma'nā as a matter of technical usage, with minimal regard for the lexical derivation of the word. ${ }^{3}$ This approach is well enough justified from the standpoint of intellectual history, and of a Wittgensteinian philosophy of language in which word meaning is conceived as a pure function of usage.

From the standpoint of Classical Arabic lexicography, though, word meanings are of two kinds: lexical and terminological. Al-ma'nā l-lughawì (lexical meaning) is the product of a word's morphology and the linguistic root from which it derives, while iștilăh (terminological convention) refers to the norms of a word's use in one specialized context or another. ${ }^{4}$ The focus of the present article is on the former kind of meaning, and its evidence is mostly conceptual, as borne out in the lexicographical literature of the early Abbasid period and the wordplay of Classical Arabic poets. I present this evidence in the spirit named by Ibn Jinnī (d. 392/1002), who says that when grammarians infer unobservable points of language change through analogy, it is taqdiran wa-hukman là zamānan wa-waqtan: "subject to appraisal and judgment, not historical consideration." ${ }^{5}$ It is in other words a matter of theory, extending partway beyond the verifiable reach of historical linguistics. So it is that I offer little here in the way of historical argument, and zero prose evidence outside of lexicography. ${ }^{6}$

1 Without the definite article, ma'nā is properly transliterated as mánan, and 'ānī as 'ānin. Ma'nā and 'āni will be retained throughout to reduce confusion.

2 Khalfallah offers a catalogue of twenty-five different senses in which ma'nā is used by alJurjānī alone, in La théorie du mánā, 9-10.

3 Thus for example Horten, Was bedeutet ma'nā, and Wolfson, Mu'ammar's Theory of Ma'nā. Richard M. Frank, who has written more on ma'nā in theology than anyone, also avoids questions of derivation, as stressed in Meanings, 261, n3. The only etymological analysis of $m a^{\prime} n \bar{a}$ known to me in modern criticism is by Idrīs al-Nāqūrī (who relies heavily on Ibn Fāris) in al-Muștalaḥ al-naqdī, 253-257.

4 Despite appearances, the distinction here is not one of diachrony and synchrony. Terminological conventions have their own histories and undergo change over time; and while lexical derivations are useful to historical linguistics, they are not historical data. ("Terminological convention" is by the way Wolfhart Heinrichs's translation for ișțilāh, in On the Genesis, 115.)

5 Ibn Jinnī, Khașā̄iș, I, 256-257, trans. Baalbaki, Historic Relevance, 111.

6 As such, my approach is the inverse of Alexander Key's in Language Between God and the Poets, although it is guided by (what I take to be) a shared disbelief in the lexicon as a cybernetic force. 
Literary evidence tells us at least this much: $M a^{\prime} n \bar{a}$ occurs neither in preIslamic poetry nor in the Qurān, and in the third/ninth century it was regarded as foreign to Bedouin speech, as we read in a report of the philologist Abū Ḥātim al-Sijistānī (d. 255/869):

Abū Hâatim said: "While the literate class (al-'âmma) say: Li-ayyi ma'nā fa'alta 'For what intention did you do [such a thing]?' the desert Arabs do not know al-ma'nā, and are not about to start saying it" (wa-lā takādu tukallimu bi-hi). This is so, [but] some of the Arabs say, Mã ma'niyyu hädhā ("What is meant by this?") ${ }^{7}$

A preoccupation with innovations of vernacular speech was general among the grammarians of Abū Hâatim's day. ${ }^{8}$ In this case, it affords a glimpse of ma'nā as a latter-day coinage, and assigns it to a community of speakers, who were the educated vulgus of cosmopolitan Iraq. ${ }^{9}$ To say that "the desert Arabs do not know al-ma $n \bar{a}$ " is to place it outside the pale of classical provenance, Bedouin speech being the standard for "pure" Arabic usage. This does not make ma'nā a vitiated word, only a late-arriving one, and an indispensable word in the vocabulary of the intellectuals of the Abbasid period.

In everyday language, it was a word for the intentional meaning of any act, acts of speaking above all, and majority opinion today holds that $m a^{\text {'n }} \bar{a}$ is "etymologically" or "originally" a word of intention..$^{10}$ In what follows, I do not contest this lexical meaning, but I do say at the outset that the semantic range of $m a^{\prime} n \bar{a}$ 's uses is not reducible to it, and that "intention" might be itself a dependent meaning, if not a derived one. $M a^{\prime} n \bar{a}$ has also an ontological referent, with "the general meaning of 'thing,' and," as Harry Wolfson says, "it is used as the equivalent of the term shay. Thus both ma'na and shay' are used as translations of the Greek term pragma, 'thing,' in Aristotle's works."11 Part of what explains the word's applicability in the dual sense of pragmata and pathèmata

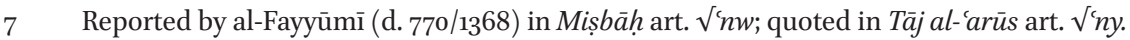

8 The Fihrist of Ibn al-Nadìm lists seven texts with the title Kitāb Mã talhanu (or yalhanu) fi-hi l-āmma, including one by Abū Hātim where this remark was likely made.

9 For al-āmma as an educated "sub-elite," see Toorawa, Ibn Abī Tāhir Ṭayfur, 1-2, and Schoeler, Genesis, 104, with reference to Jāhịiz, Bayān, I, 137.

10 Versteegh, Ma'nā (A.), VI, 346: "Etymologically, ma'nā is what the speaker intends to say." Kouloughli, Ma'nā, III, 160: "The noun ma'nā is originally a verbal noun (mașdar) formed on the verb 'anāa/ya'nī, which properly means 'to aim at something.' Ma'nā consequently means, primarily, "the act of aiming at something."

11 Wolfson, Philosophy of the Kalam, 115. Haq, Names, 26-27 points out that this usage was current in the second/eighth century. The interplay between ma'nä's noetic and ontological senses in the work of al-Jāhiziz (d. 255/869) is pointed out by Larkin, Theology of Meaning, 33-34. 
(things in the world and affections of the psyche) is that the root verb-complex from which the Arabic word derives is not limited to a verb of intending. As we shall see, it also includes a verb of ostension and making manifest, which Abdelhamid Sabra connects expressly to ma'na when the word is used for an "accidental property" of a substance. ${ }^{12}$ And it includes a verb of captivity, which gives the present article its title. The plurality of root meanings from which $m a^{\prime} n \bar{a}$ could potentially be derived is part of what I am calling the lexical preconditions for its polysemy.

"Preconditions," I am careful to say, and not "determinants." Meaning really is a matter of use, but use is guided by form. And $m a^{\text {'n }} \bar{a}$ 's form is pluripotential. For its every other meaning to have been attracted subsequent to ma'nä's coinage as a word of intention is to my mind a far-fetched explanation. What bars all other meanings from consideration, with respect to the seldom-raised question of ma'nă's derivation? The question cannot be dismissed without exploring $\sqrt{ }{ }^{\prime} n w / y$, the verbal root on which $m a^{\prime} n a \bar{a}$ is constructed. In so doing, I have come back with two arguments. One (ahead at 2.3) is that the noetic meaning of "intention" (signified by the verb 'ana $y a^{\prime} n \bar{\imath}$ ) correlates metaphorically with the carceral and corporeal meaning of "captivity" (signified by the verb 'an $\bar{a}$ $y a^{i} n \bar{u}$ ), and may stem from it. Another (2.4) is that the ostensive meaning "to put forth" (signified by both verb forms) might be predicated on the fact of captivity as well, insofar as the captive's interiority is vulnerable to disclosure under duress.

I am also careful to say "polysemy." My critics are liable to object that what the root meanings of $\sqrt{ }{ }^{\prime} n w / y$ present is rather a case of homonymy, i.e., the formal coalescence of semantically-unrelated lexemes. What follows here is my response to that objection.

\section{Morphology of ma'nā}

$M a^{c} n \bar{a}$ 's form is so little discussed that it is almost hard to identify a mainstream opinion in the matter. ${ }^{13}$ By some it is conceived as a passive participle, i.e., a thing "intended" or "meant." One problem with this is that ma'niyy, the normative or "true" passive participle of 'anā ya'nī, is already attested (as in Abū Hātim's statement above)..$^{14}$ The claim is then encountered that ma'nā is a "lightened" form (takhfif) of ma'niyy. But while takhfif (the elision of hamza ma'nà: Some Reflections, 249, and furthermore Frank, Yā Kalām, 3-4.

13 Kouloughli's formal analysis (above at nı) stands out in this regard.

14 Wright's Grammar, I, 91 вС (\$170).
} 
and shadda) is a regular fact of Arabic morphology, the vocalic shift of $\bar{l}>\bar{a}$ is an anomaly unexplainable by takhfif. In an 1896 lithographic edition of Mullā Jāmī's al-Fawā’id al-Piyā̄iyya, an anonymous scholiast writes: "[To derive ma'nā from ma'niyy] comes closest in terms of meaning, but in terms of form it is way off. No parallel case of takhfif can be found in the speech of the Arabs." ${ }^{15}$

The range of meanings adduced for ma'na does not reduce to the "thing intended" of passive participle al-ma'niyy, and calls for a lectio dificilior. We find it in the Kitāb al-Furūq of Abū Hilāl al-'Askarī (d. ca. 400/1010):

Ma'nā is a verbal noun derived from the verb 'anāya'nī. Its form, maf'al, can be used for either the noun of place (ism makān) or the verbal noun - and here it is a verbal noun, as when you say dakhaltu madkhalan hasanan ("I entered, making a good entrance"), using madkhalan [adverbially,] as you would the verbal noun dukhūlan.16

Either of these possibilities gives a likelier basis for ma'nä's multivalence than the participle ma'niyy, "a thing intended." But what would it mean for ma'nā, the word for "meaning," to be formed as a noun of place?

The answer hinges on a class of verbal noun (mașdar) that is formally identical and conceptually very close to the noun of place, called by grammarians the mașdar mìmi ("verbal noun beginning with the letter mìm"). ${ }^{17}$ Rather than action itself, the mașdar mimi names the abstract fact or circumstance of an action's taking place. ${ }^{18}$ "As is well known," writes Meir Bravmann, "such nouns may be used in a concrete meaning — a use in which they are ordinarily defined as nomina loci - but also in an abstract meaning, that is: as nomina

15 Interlinear commentary to Fawä̀id, 5 (lines 3-4): Hādhā l-wajh aqrab al-wujūh ma'nan waab'aduhā lafžan ma'a annahu lā yūjadu li-l-takhfî́ nazīrun fì kalām al-'arab. What Jāmī (d. 898/1492) himself says in Fawā̇id (being his commentary on al-Käfiya fì l-naḥw of Ibn al-Hājib, d. 646/1249) is the following:

Al-ma'nā is what is meant by a thing (mayuqșadu bi-shay'in). Its form, maf'al, is either a noun of place, meaning a "goal" (al-maqșid); or it is a mașdar mìmı used as a passive participle; or it is a lightened form of mániyy, which is the [true] passive participle, analogous to marmiyy "thrown" [the passive participle formed on ramā yarmī].

16 'Askarī, Furūq, 36.

17 Mașdar mìmī seems to have entered use as a term of Arabic grammar after the Abbasid period; the earliest mention known to me is Jāmī's. It was the subject of a grammatical treatise by Abū l-'Arfān Muhammad b. 'Alī al-Ṣabbān al-Miṣrī (d. 1206/1791-2), Risāla fí l-mașdar al-mìmī wa-ismay al-makān wa-l-zamān. See (in addition to Bravmann's aheadcited Studies in Semitic Philology) Aro, Der Mașdar al-mīmī, and Roman, Sur la constitution, 121-124.

18 Compare the interrogative "question" named by verbal noun su'äl (Spanish pregunta) to the circumstantial "occasion for inquiry" named by mas'ala (Spanish cuestión), which is a mașdar mìmī formed on the same root. 
actionis (infinitives)."19 Their formal identity is mirrored by the semantic overlap between noun of place and mașdar mimī, each of them being the "scene" of the action in its own way.

At the root of the word is a "defective" verb (fil nāqis ) whose final radical is a long vowel (harf mu'tall). Exactly which defective verb cannot be affirmed through morphology alone, for there are three separate verb conjugations formed on $m a^{\prime} n \bar{a}^{\prime}$ s root:

TABLE 1 I ${ }^{\text {st }}$-form conjugations of $\sqrt{ }{ }^{\mathrm{c}} \mathrm{nw} / \mathrm{y}$

\begin{tabular}{|c|c|c|}
\hline Perfect & Imperfect & Verbal nouns (excluding ma'nā) \\
\hline 'anā & ya'nū & 'unuww, 'anā', 'anwa \\
\hline 'anā & $y a^{c} n \bar{\imath}$ & 'ināya, 'uniyy, 'anya, 'anā' \\
\hline 'aniya & ya'nì & 'ināya, 'uniyy \\
\hline
\end{tabular}

Most lexicographers see two separate roots behind these verbs. The first conjugation ('ana $\left.y a^{\prime} n \bar{u}\right)$ they identify with $\sqrt{ }{ }^{\prime} n w$, and the other two with $\sqrt{ }{ }^{\prime} n y$. One exception is Jamāl al-Dīn b. Mukarram b. Manzūur (d. 711/1312), compiler of Lisān al-'arab (henceforth Lisān), where $\sqrt{ }{ }^{\prime} n y$ and $\sqrt{ }{ }^{\prime} n w$ are dealt with in one article $\left(\sqrt{ }{ }^{\prime} n \bar{a}\right)$. But whether they are conceived as separate roots or one root with three vowelings makes little difference. The affiliation of $\sqrt{ }{ }^{\prime} n w$ and $\sqrt{ }{ }^{\prime} n y$ is marked by too many shared meanings and formal reflexes to be denied. Ma'na itself is one such overlap: in terms of form it derives indifferently from either root. Whether the third radical of a defective verb is $w \bar{a} w$ or $y \bar{a}$, it becomes alif maqșūra in its maf'al form. ${ }^{20}$

Corresponding to this complex of form is a complex of word-meanings that can all be connected to $m a^{\prime} n \bar{a}$ in some way. This is not to claim that they are equally implicit in the word's origin, nor that all are engaged whenever ma'na $\bar{a}$ is spoken and heard. My thesis rather is that the meanings of $\sqrt{ }{ }^{\prime} n w / y$ are coaligned in a latent paradigm that predicates noetic intention and phenomenal exposure upon bodily captivity. To examine the relations between them is to uncover a structural model for meaning without obvious parallels in the hermeneutic and rhetorical traditions of the post-Hellenic West.

19 Bravmann, Studies in Semitic Philology, 236.
20 Wright's Grammar, I, 127D-128B (§224). 
Among the lexicographers, the greatest effort to isolate its linguistic meaning was made by Abū l-Ḥusayn Aḥmad Ibn Fāris (d. 395/1004). Ibn Fāris was in many ways a maverick figure, whose biography brings contrarieties together. A highly original linguistic theorist, his speculative daring was combined with an ultra-conservative position on the origin of language. The Arabic language was revealed all at once by God to Adam, he says in al-Sāhhibi fi figh al-lugha (The Statutes of Language for al-Ṣāhib b. 'Abbād), and its origins are therefore a matter of divine inspiration (tawqïf) rather than human convention and coinage (muwāda'a wa-știläh). His rejection of the conventional basis of human language is best understood as a statement of opposition to Mu'tazilism less from the theological standpoint of the Ash'ari school, it seems, than in the spirit of traditional hadìth scholarship. But Ibn Fāris's heterodoxy as a language scholar was unhampered by religious orthodoxy. Indeed, for modern authorities he often goes too far. Jaakko Hämeen-Anttila calls his etymologies "fantastic"; "frequently arbitrary and unconvincing," says Ramzi Baalbaki. ${ }^{21}$ It is in his resort to the intuitive etymological strategies known collectively as al-ishtiqāq al-kabìr ("grand derivation") that Ibn Fāris goes widest of mainstream Arabic morphology. In the present case, however - the case of al-ma'na - no such strategies enter, and Ibn Fāris makes no morphological leaps outside of normative ishtiqāq șaghïr ("lesser derivation"). In fact he says little about ma'nā and its congeners that Ibn Manzuur (a cautious etymologist) does not repeat after him in Lisān.

\section{$2 \quad$ Ma'nā apud Ibn Fāris I: Maqūȳis al-lugha}

In the etymological dictionary Maqūyis al-lugha (Analogical Templates of Language), Ibn Fāris's combined entry for $\sqrt{ }{ }^{\prime} n w / y$ begins with a list of three root meanings $(u s ̣ u ̄ l):$

(1) Being intent upon a thing, such that one's concentration and desires are bent upon it

(2) Abasement and subjugation

(3) The appearance of a thing and its standing forth ${ }^{22}$

21 Hämeen-Anttila, review of Zammit, Comparative Lexical Study, 296, n4; Baalbaki, Arabic Lexicographical Tradition, 351.

22 Ibn Fāris, Maqāȳ̄s, IV, 146: Ușūl thalātha: al-awwal al-qașd li-l-shay' bi-nkimāshin fì-hi wa-hirșin 'alayhi, wa-l-thānì dāllun 'alā khuḍū'in wa-dhüllin, wa-l-thālith zuhūr shay'in wa-burūzuhu. 
These meanings are distributed among $\sqrt{ }{ }^{\prime} n w / y^{\prime}$ s I ${ }^{\text {st }}$-form conjugations in the following way. Reflexes of A.'anā ya'nū are used to designate meanings (1) and (3), and reflexes of B.'anā ya'nī designate (2) and (3). Conjugation C.'aniya ya'n $\bar{\imath}$ meanwhile is used for both (1) and (2) but not (3). ${ }^{23}$ The relations of these forms and meanings may be appreciated visually in Table 2 .

In Maqāyis al-lugha, Ibn Fāris hints at a metonymic relationship between meanings (1) and (3) where he says "al-ma'nā is the intention (al-qașd) that stands out in a thing and becomes apparent when that thing is looked into," as if (3) were the practical consequence of $(1) \cdot{ }^{24}$ Although he does not establish any dependent relationship between them, I will venture some hypotheses in this connection. One is that the psychological "intention" of meaning (1) is a metaphorical correlate of the bodily "captivity" of (2). Another is that meaning (3)'s sense of "becoming apparent" is a metonymic extension of (2) and (1). Again I stress that diachronic argument is beside the point of this article, which is a survey of semantic overlaps that have so far passed unremarked in modern scholarship. Taken together, they suggest a paradigm for the becoming-manifest of meaning that is not organized around the operation of a sign. I do not call this a new paradigm, for it is assuredly very old; instead I call it a latent paradigm, even though the evidence for it lies on the browsable surface of Classical Arabic philology. ${ }^{25}$

Ibn Faris's entry for $\sqrt{ }{ }^{\prime} n w / y$ continues:

[The verb in the phrase] 'unitu bi-l-amr ("I was concerned by the matter") or bi-l-hāja ("by a necessity") is of the first [root meaning]. Ibn al-A 'rābì (d. 231/846) and others have said that [active-voice] 'aniya and [passivevoice] 'uniya are both used in this context (Aniya bi-häjatī wa-'uniya), though al-Așma'i denied that 'aniya is so used. And [ $\mathrm{v}^{\text {th }}$-form verb] ta'anna is used in the same way.

23 As Table 1 shows, conjugation C lacks a dedicated mașdar of its own. Both its verbal nouns are shared with conjugation $\mathrm{B}$ - a sign perhaps that conjugation $\mathrm{C}$ is posterior to $\mathrm{B}$.

24 Ibn Fāris, Maqāȳ̄s, IV, 149: al-ma'nā huwa l-qașd alladhì yabruzu wa-ẓ̌ara fì l-shay' idhā buhitha' 'anhu.

25 Constraints of space and expertise enforce my silence about cognates of $\sqrt{ }$ ' $n w / y$ in other Semitic languages, beyond noting that the Hebrew verb 'anâ is similarly ramified in its meanings ("to answer," "to be afflicted," "to be occupied with," and "to sing"), posing a crux at Exodus 32:18. Makujina, Additional Considerations, 40; see also Good, Exodus 32:18. 
TABLE 2 Three paradigms of $\sqrt{ }{ }^{c} n w / y$ with derived verbs and substantives (source: Lisān al-'arab art. $\left.\sqrt{ }{ }^{`} n \bar{a}\right)$

\section{A. 'anā ya'nū}

(2) intr. "be subjugated"

(Q 20:111 Wa-'anati l-wujūhu), verbal nouns 'unuww, 'anwa, 'anä' "submission," act. part. 'ānī "captive"

\section{C. 'aniya ya'nì}

(2) intr. "be made captive"

(1) intr. "be perturbed," act. part. 'ānī "preoccupied"

\section{B. 'anāya'nī}

(1) intr. "become perturbed," v.n. 'ināya, 'unizy, 'ană' "concern, preoccupation," act. parts. 'ānī, 'anī "preoccupied"

(1) tr. "affect, concern, provoke anxiety in" + acc. (Q 80:37 var. shä’nun ya'nīhi), v.n. 'ināya, 'uniyy, 'anya, 'anā' "care" pass. part. ma'niyy "what is intended"

(3) intr. 'unyān "title"

(3) tr. "put forth," no verbal noun specified

(3) tr. "reveal, express," v.n. 'unuww e.g. 'Anawtu l-shay'a (I put forth the thing).

\section{DERIVED VERBS}

II ${ }^{\text {nd }}$ form 'anna "take prisoner, keep confined" + acc.

$\mathrm{IV}^{\text {th }}$ form $a^{\text {' }} n \bar{a}$ "cause to remain in captivity" + acc.
II ${ }^{\text {nd }}$ form 'anna "make a matter of concern"

+ double acc.

III ${ }^{\text {rd }}$ form 'ānā intr. "be vigilant"

IV $^{\text {th }}$ form $a^{\text {tn }} \bar{a}$

tr. "make a matter of concern"

$\mathrm{V}^{\text {th }}$ form ta'annā: tr."afflict" + acc.;

intr. "undergo affliction"

VIII ${ }^{\text {th }}$ form $i$ tana "become concerned" 
Its verbal nouns are 'ināya and 'uniyy, its passive participle ma'niyy, and its active participle 'ānì. Al-Farrā' (d. 207/822) said: "For a man to be [actively] 'annīabout my affair means the same as for him to be [passively] ma 'niyyun by it" (rajulun 'ānin bi-amrī, ay ma'niyyun bi-hi). And he recited [the anonymous rajaz verses]:

'Ānin bi-qușwāhā țawìlu l-shughli

la-hu jafirāni wa-ayyu nabli

Intent on the remotest [beast in the herd], long at his task, he has two quivers - and what arrows [they contain]!

\subsection{Ergativity}

In the above passage, the verb is equally applicable in an intransitive sense or a transitive one, such that to be actively 'anni (concerned) about something is the same as being passively mániyy (concerned) by it. A language's potential for fluctuating transitivity of this kind is called "ergativity," and it is more commonly observed in English than in Arabic. ${ }^{26}$ Whereas the English verb "break" is used for transitive and intransitive action equally (such that "Robin broke the window" and "The window broke" may both be said), the Ist-form Arabic verb kasara is used for transitive breakage only; to express the intransitive force of "The window broke," one uses $\mathrm{v}^{\text {th }}$-form takassara or $\mathrm{VII}^{\text {th }}$-form inkasara. ${ }^{27}$ The challenge that ergativity poses to lexicography is described by Eugene Nida:

For example, in the two sentences The men marched around and The guard marched the men around, is it better to set up one meaning of march, or two meanings, one intransitive and the other transitive? In general, dictionaries list two different meanings. But if this procedure were followed consistently, one would have to list several different meanings for open in the sentences: He opened the door with a key, The door opened, A key opened the door, The door was opened with a key. In reality,

26 Davidse, Transitivity/Ergativity, 107, upholds Michael Halliday's opinion that "all languages are a mixture of ergative and transitive."

27 Ergative verbs really are less common in Arabic than English. Zāda, "increase," and naqașa, "decrease," come to mind among the It-form verbs, and a few others. Derived forms with ergative use include $\mathrm{II}^{\text {nd}}-$ form șarraha $a$, "to purify"/"become pure," IV $\mathrm{V}^{\text {th}}$-form aqūma, "to cause to stand"|“to stay," and see the chapter from Ibn Fāris's Șāḥibī cited just ahead. 
however, the verb open refers only to the change of state of the door, from being closed to being open. It would seem more economical and relevant in approaching the problem of meaning to consider the meaning of open to be the same in all instances. The differences in the meanings of the utterances are then simply a matter of the co-occurrence in various transformations of the agent, affected, and instrumental constituents.... The meaning is thus a part of the total configuration, not a component added to a particular constituent in the configuration. ${ }^{28}$

If all the transitive and ergative shadings of open might be reduced to a single change of state, then what about the change named by B. 'ana $y a$ ' $n \bar{\imath}$, which means both an operation of the mind and an external provocation? A "seizure of attention" is what it seems, represented from two diathetic perspectives: a quasi-passive (but grammatically active), intransitive one that is psychological and interior, and a transitive one that is phenomenological and affects the subject from without.

Although Ibn Fāris had no dedicated term for ergativity, he makes explicit note of the phenomenon in a chapter of al-Sāhibi called "Things sometimes have the same meaning whether they come [expressed] in the passive or the active voice" (Bāb al-shay' ya'tī marratan bi-lafž al-maf'ül wa-marratan bi-lafž al-fácil wa-l-ma'nā wāhhid). In this chapter, B. 'anā ya'ñ̄ is mentioned specifically, and is demonstrated with the same rajaz hemistich as in Maqāyis art. $\sqrt{ }{ }^{\prime} n w / y$ (with this variation: 'Ānin bi-ukhrāh $\bar{a}$, "Intent on the very last [beast in the herd]..."). ${ }^{29}$

Transitivity does not fluctuate so much in every paradigm of $\sqrt{ }{ }^{\prime} n w / y$. The opinion in Maqāyis and elsewhere is that conjugation C.'aniya ya'n $\bar{\imath}$ is used for the intransitive modes of meanings (1) and (2) only. Meanwhile, conjugation A.'anāya'nū works both ways when used of meaning (3), but for meaning (2) - the meaning of "abasement and subjection" - Ibn Fāris supplies no transitive instances. Nowhere in fact is A.'an $\bar{a}$ ya n' $\bar{u}$ shown to take a direct object, as do its derived II $^{\text {nd }}$ and IV ${ }^{\text {th }}$ forms ' $a n n \bar{a}$ and $a^{\text {' }} n \bar{a}$. And so I exclude any transitivity of meaning (2) from Table 2 above and Table 3 on the next page.

$28 \quad$ Nida, Exploring Semantic Structures, 41.

29 Ibn Fāris, Șāhibī, 203. 


Verb Intransitive meaning Transitive meaning
A. 'anāya'nū
(2) to be made captive
(3) to flow
B. 'anā ya'nī
(1) to have one's attention seized
(3) to put forth
C. 'aniya ya'nī
(1) to have one's attention seized
(2) to be made captive
(1) to occupy someone's attention
(3) to put forth
No transitive meaning

\subsection{Captivity}

Concerning A.'anā ya'nū, recorded scholarly debate has little to do with transitivity. Instead, the issue was whether it could be used of subjugation in the aftermath of a peaceful surrender, or whether 'anwa (its verbal noun) is essentially subjugation by force of arms. ${ }^{30}$ Ibn Fāris summarizes the debate in Maqāȳis art. $\sqrt{ } n w / y$ :

'Anwa is "conquest" (al-qahr). "We took it in 'anwa" is said to mean "We conquered it by the sword." [Alternately,] "I came to you as an 'ān $\vec{\imath}$ is said to mean "I came submissively." And some say that 'ānwa is "obedience" $\left(a l-t+\bar{a}^{\mathfrak{c}} a\right) \cdot{ }^{31}$

The distinction is of little consequence; either way, 'anwa is as Ibn Fāris says "abasement and subjugation." His discussion of A. 'anā ya'nū begins:

30 The first to assert that 'anwa could refer to peaceful submission seems to have been al-Farrā' in Ma'ānī al-Qur'ān, II, 192-193, as expounded by Ibn al-Anbārī (d. 328/940) in al-Z̄āhir fı̀ma'ānı̄ kalimāt al-nās, I, 312:

According to al-Farrä', there are two sides to al-'anwa. The first is its use that means "taking a country by conquest and abasement (bi-l-qahr wa-l-dhull). The other way one says it means "taking a country through the submission of its inhabitants and [their] obedience, with no battle fought" ('an taslïmin min aṣhābihä la-ha wa-țāatan bi-lā qitāl).

By virtue of this ambiguity, 'anwa was reckoned by some to be among the addād (words that are used for two contrary meanings), as in Abū Ḥātim al-Sijistānī's Kitāb al-Aḍdād, 126, as well as that of Abū l-Ṭayib al-Lughawī (d. 351/962), II, 491-493, and in Kitāb al-Aḍdād, 79-8o, by the same Ibn al-Anbārī. 
The second root is 'ana ya'nū, meaning "to submit" (khada'a). [Active participle] 'ānī means "a prisoner" (al-asīr). Abū 'Amr (al-Shaybānī, d. 213/828) said [using the $\mathrm{IV}^{\text {th }}$-form imperative]: A'ni hādhā l-asìra means "Prolong his captivity until the leathern thongs that bind him are dried out." Zuhayr (b. Abī Sulmā, fl. sixth c. CE) said (meter: wäfir):

Wa-law lā an yanāla Abā Ṭarīfin

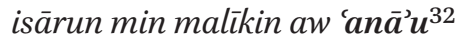

If Abū Țarif had not been taken hold of by captivity, or imprisonment fit for chattel ...

According to al-Khalīl (b. Aḥmad d. 175/786), 'unuwww and 'ană' are verbal nouns for the 'anni, such that the captive is said to concede to al-'unuww. ${ }^{33}$ Anyone who undergoes abasement and defeat is an 'āni. God, be He exalted, says: wa-'anati l-wujūhu li-l-hayyi l-qayyümi ("Faces will be brought low before the Living and the All-Sustaining ..."). ${ }^{34}$

Here Ibn Fāris refers to the only canonical occurrence of $\sqrt{ }{ }^{\prime} n w / y$ in the Qurān. This is from Sürat T⿱亠乂 $H \bar{a}$ 's description of the rigors of the Last Day. The whole àya $(\mathrm{Q} 20: 111)$ runs as follows:

Wa-'anati l-wujūhu li-l-hayyil-qayyūmiwa-qad khāba man ḥamala zulman

Faces will be brought low before the Living and the All-Sustaining, and woe betide any who bear [responsibility for] oppression.

What A.'an $\bar{a} y a^{\prime} n \bar{u}$ names here is the assumption of a submissive posture or position. Albeit unspecific, it is clear that on the Last Day no one is free to turn away with head held high. ${ }^{35}$ The suggestion of bodily prostration is redoubled

32 In Tha'lab's commentary on Zuhayr's dīwān (Sharh Shi'r Zuhayr, 69), the verse appears with liha $\bar{a}$ ' (verbal abuse) in place of ' $a n \bar{a}$. The editor identifies Abū Țarif as "A man of Banū 'Abdallāh b. Ghațafān who was made a prisoner of the Banū 'Alīm," but notes that one commenter identifies him with Zuhayr himself $(280, \mathrm{nl})$.

33 Al-'unuwww wa-l-'anā' mașdar li-l-ānī; yuqāl 'ānin aqarra bi-l-'unuwww, wa-huwa l-asìru. This

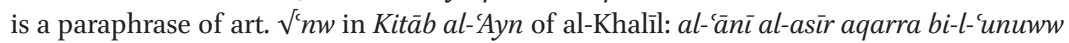
wa-l-'anā'wa-humā mașdarān.

34 Ibn Fāris, Maqāyìs, IV, 146-147.

35 In the view of some commentators, 'anati l-wujüh refers to the faces of disbelievers only, as at Sürat al-Mulk (Q 67:27): "When those who disbelieve see it approaching, their faces will be aggrieved ..." (sỉat wujūhu lladhina kafarū ). 
in a verse attributed to the Prophet's contemporary, the poet Umayya b. Abi l-Ṣalt (meter: țawīl):

\section{Malīkun 'alā 'arshi l-samāi muhayminun \\ li-'izzatihi ta'nū l-wujūhu wa-tasjudu ${ }^{36}$}

Upon the throne of heaven [He is] Master and Overseer;

faces are brought low before His glory, and press the ground.

Whereas B.'anā ya'nī is for the seizure of a subject's attention, with A.'ana $y a^{\prime} n \bar{u}$ it is a subject's physical autonomy that is being seized, as the subject gives into domination by another. The change of state it names is from a state of freedom to one of constraint and captivity. The physicality of 'anwa may be metaphorical, or a literal fact of "leathern thongs" (al-qidd) as mentioned above by al-Shaybānī. The evidence for my suspicion that the bodily meanings of 'anwa precede the psychological meanings of 'ināya begins with A. 'anā ya'nü's archaic ring. Outside of Classical Arabic poetry, and here and there in hadith, the verb is not commonly heard. B.'anā ya'nī, by comparison, is still in everyday use.

It is not the case that A. precedes B. in the observable record of Arabic literary history. B.'anā ya'nī is heard all the way back, and even occurs in a noncanonical reading of Sürat 'Abasa (Q 80:37). Where the canonical reading says:

\section{Li-kulli mri’in minhum yawma'idhin sha'nun yughnīhi}

On that Day, every man's circumstance will suffice him

al-Ḥasan b. 'Alī b. Abī Ṭālib (d. 5o/67o) is said to have read it thus:

\section{Li-kulli mri'in minhum yawma'idhin sha'nun ya'nihi ${ }^{37}$}

${ }_{3} 6$ Dīwān Umayya, 39. Ibn al-Anbārī adduces a close variant of this verse in his above-noted Kitāb al-Aḍdād, 8o; for something similar by Zayd b. 'Amr b. Nufayl, see Kitāa al-Aghānī, III, 84.

37 Ibn Khālawayh, Mukhtașar, 189. The notice by 'Abd al-Lațîf al-Khațīb (Mújam al-qirāāàt, x, $314, \mathrm{n} 4$ ) crediting Ibn al-Muqaffa' as a transmitter of this reading turns out (on comparison to al-Khafājī, Hāshiyat al-shihāa $, \mathrm{IV}, 370$ ) to be a misspelling of the name Ibn al-Muqannac. Sürat 'Abasa (Q 80:37) with ya'nīhì is not in any of the seven or ten canonical (șahịh) readings of the Qur'ān. Only in the reading of Muḥammad b. 'Abd al-Rahmān b. Muhayṣin (d. 123/740) is it upheld. Ibn Muhayșin was reckoned the most accomplished grammarian of Mecca, where his reading was nevertheless superseded by that of 'Abdallāh b. Kathīr alDārī (d. 120/738). See Ibn al-Jazarī, Ghāyat al-nihāya, II, 167 . 


\section{On that Day, every man's circumstance will concern him.}

As in many cases of Qur'annic multiformity, the variance here is grammatological, hinging on the absence or presence of a single $\operatorname{dot}($ ghayn $\dot{\varepsilon}$ vs. 'ayn $\mathcal{\varepsilon})$. In exegetic terms it is not a terribly significant variant. ${ }^{38}$ It is however a sign of meaning (1)'s strong affinity with meaning (2), occurring as it does in another description of the Last Day. ${ }^{39}$ Not that the semantic connection between (2) and (1) was in much doubt; the claim of a metaphorical relationship is fairly uncontroversial. Nor is it the only case where divergent vocalizations of $a$ harf mu'tall correspond to concrete/abstract pairs of meanings: $\mathrm{cf}$. $\sqrt{d n w}$ "to be low" and $\sqrt{d}$ ny "to be base"; $\sqrt{ } r k h w$ "to be pliable" and $\sqrt{ } r k h y$ "to be easy"; and $\sqrt{\operatorname{tg} h w}$ "to flood" and $\sqrt{t}$ ghy "to be excessive in anger."40 Between A.'anwa (2) and BC. 'ināya (1) the relation is the same: physical "captivity" is what is undergone by the body, and noetic "captivation" is what is undergone by the mind.

With that established, my basis for according notional priority to (2) is simply that the metaphor only works in one direction. For the captivation of a subject's attention, physical restraint is a natural figure — no rare conceit in verse, as in a zahriyya (flower-poem) by Abū l-Ḥasan b. 'Alī that begins (meter: tawül):41

$3^{8}$ Ibn Jinnī (Muhtasab, II, 417.) interprets the difference as one of degree:

A thing may "concern" a man (qad ya'nīhi) without "voiding his needs" (wa-lā yughnīhi). As an example: if a man is in possession of a thousand dirhams and a hundred are taken from him, it "concerns" him without "leaving him in no need" for vigilance and attention to the remainder of his wealth. The matter which "voids his needs" is the direr necessity and the higher consideration. This reading is not only clearer, but better known.

39 Another example of B.'anāya'nī on the Last Day which perhaps echoes Hasan's recitation of Sürat 'Abasa (Q 80:37) is heard in a sermon of 'Umar II (d. 101/720), who calls it

A Day on which rich and poor will be seen as equals in what befalls them, and when you will be concerned with a matter [of such magnitude] that if it were the stars' concern they would go dim (wa-la-qad 'unitum bi-amrin law 'uniyat bi-hi l-nujūmu lankadarat), and if it were the mountains' concern they would dissolve, and if it were the earth's concern it would split open. (Abū Nu'aym al-Iṣfahānī (d. 430/1038), Hilyat al-awliy $\vec{a}, \mathrm{v}, 291-292)$.

40 This effect can be observed in some cases of metathesis (qalb), as with $\sqrt{ }{ }^{c} y$ th and $\sqrt{ }$ thy which both mean "to ruin," and on which al-Rāghib al-Iṣfahānī (d. ca. 409/1018) remarks: "Ayth and 'uthiyy/uthuww are nearly alike; but 'ayth is mostly used in relation to that which is perceived by sense; and 'uthiyy and 'uthuww in relation to that which is perceived by judgment" (quoted in Lane's Lexicon art. $\sqrt{ }$ 'yth).

41 This Abū l-Ḥasan was a contemporary of the poetry anthologist of Seville, Abū l-Walīd Ismā̄ēl b. 'Āmir al-Ḥimyarī (d. 440/1048), and the poem is in al-Ḥimyarī's al-Badī fì wașf $a l-r a b \bar{\imath}, 119$. 
Arā l-narjisa l-tibriyya ya'nū la-hu l-fikru wa-yaqșaru 'an awșāfihi l-nazmu wa-l-nathru

I see the gilt narcissus, toward which [my] thoughts are bent; poetry and prose fall short of its description.

Artful plays on $\sqrt{ }{ }^{\prime} n w / y$ are not encountered in late flower poetry only. We find them in the prison poems of 'Adī b. Zayd (d. ca. 6oo CE), where there is a decided flourish in the juxtaposition of mental captivation with the institutional fact of 'Adī's captivity (verses 15-18 of a 32-verse qașīda, meter: wäfir):

Wa-mā dahrī bi-an kuddirtu faḍlan wa-lākin mà laqütu mina l-ájībi wa-mā hādhā bi-awwali mā ulāqū mina l-hidthāni wa-l-'araḍi l-qarïbi

wa-mà țalabì su'àlan ba'da khubrin namāhu l-mū diēuna ilā l-sha'ūbi wa-mā sha'nī bi-hi wa-l-fayju hawlì wa-hammì law 'anaytu bi-hi mușïbi ${ }^{42}$

What is my fated end? My worth besmirched, no cause for gladness anywhere I find.

What are my sufferings - mere beginnings of the accidents and mishaps just ahead?

What is my suppliant petition, now that I know what hurtling toward death is like?

How am I circumstanced? Around me guards are posted. If I become captivated by this, my anxiety will strike.

In this last verse, 'anaytu's voweling identifies it with B. 'ana $y a$ ' $n \bar{\imath}$, whose psychological meaning (1) is clear from context. Law 'anaytu bi-hi might be translated here as "If I give mind to it." But to say that his anxiety results from mindfulness of captivity, and not captivity itself, seems to me a case of kināya (figurative allusion) that is very like a jest. The word for his inner state alludes to his outer state, i.e., imprisonment under guard, as mentioned in the same verse.

The verb is used ironically in another poem of 'Adi's, such that mental captivation and physical captivity are signified at the same time. This is a pair of verses coming after the description of a rainstorm (wasf al-mațar), marking

$42 \operatorname{Dīwān~'Ad̄̄,~} 39$. 
the poem's transition to the next theme (verses 13-14 of a $5^{0}$ verse qașida, meter: khafif):

\author{
Lam ughammid bi-hiwa-sha'ȳ̄ bi-hi mā \\ dhāka annī bi-șawbihi masrūru \\ bal 'anānì qawlu mrìin lam yuqal fì \\ -hi șawābun badā wa-là taqdìru 43
}

My eyes never closed in sleep while it was going on. My vexation has nothing to do with the downpour, which brought me gladness. Nay, what troubles me/imprisons me is a man's statement, in which everything said was plainly in error and without discernment.

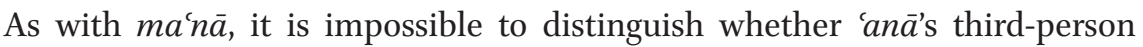
masculine singular perfect form is a reflex of B.'anā ya'ñ or A.'anā ya'nū. Context here demands both verbs' meanings. The poet's joy in the rainstorm is contrasted ( $b a l)$ with the mental "troubling" to which he has been subjected. The source of the trouble is "a man's statement" (qawlu mriin), i.e., the charges on which 'Adī was imprisoned by al-Nu'mān III (the Lakhmid king who ruled al-Hīra from ca. 580 to $602 \mathrm{CE}$ ). The resulting captivity is no mere metaphor for distress, but actual imprisonment: 'anānì qawlu mrïin means the man's accusation has rendered 'Adī a captive.

\title{
2.3 Abstract and Concrete
}

The ironic use of 'ana in 'Adî's poems demonstrates that the connection between physical captivity and mental captivation was evident and ripe for exploitation in early Arabic poetry. What it does not demonstrate is the priority of either meaning, and so instead of identifying one or another as the derived meaning, I call them metaphorical correlates of one another.

Still and all, to contest the thesis that words for psychological events were preceded by words for physical ones is to go against an enduring linguistic insight of the Enlightenment, which Giambattista Vico (1668-1744) elevated to a "universal principle of etymology in all languages: words are transferred from physicalobjectsand theirpropertiesto signify whatisconceptual and spiritual."44 Moses Mendelssohn (1729-1786) said the same for ethical concepts, "inasmuch as we compare the derivative moral sense of the words with their original

\footnotetext{
43 Ibid., 86.

44 Vico, New Science, 97 (Axiom 63).
} 
physical sense." ${ }^{\prime 5}$ It is not that word derivation never goes the other way: certainly it happens that corporeal things come to be called by names with abstract meanings. It's just not the prevailing direction in which change of usage tends to go. I say this in the face of linguist David Justice's obscure contention that "the passage from concrete meanings to abstract and vice versa are both so common in semantic history that it is difficult to know which was original." ${ }^{\text {. }}$ Vice-versa cases are too much harder to bring to mind. ${ }^{47}$

Abstraction of course takes different forms. By some it has been represented as a property of verbs relative to nouns, and a marker of their historicallinguistic posteriority. ${ }^{48}$ This is not what I suggest here. I acknowledge that abstract verbal nouns are often used to name concrete results, instruments, or agents of the verb in question..$^{49}$ It also happens that words for abstract properties are used to mean concrete substantives (e.g., curiosities, notions, novelties). The issue here is one of relative abstraction among verbal reflexes of the same root - or perhaps relative corporeality describes it better. While A. 'ana $y a^{\prime} n \bar{u}$ names a state of humility and helplessness that is visible and tangible (with physical restraints placed on the body as a matter of course), the state of B.'anāya'ni is an intangible analogue proper to the nafs (soul), qalb (heart), șadr (chest), or anywhere thought and feeling may take place. This is the kind of relative abstraction I posit between these differently-voweled reflexes of $\sqrt{ }{ }^{\prime} n w / y$.

None of the Abbasid grammarians or lexicographers can be found to predicate the noetic "captivation" of $\sqrt{ }$ 'ny on the bodily "captivity" of $\sqrt{ } n w$, and in

45 Mendelssohn, Morning Hours, 92. The doctrine's best-known statement is by l'Abbé de Condillac (1715-1780):

$[\mathrm{T}]$ he first names that were given to what we are capable of feeling signified sensible actions alone. Later, as mankind gradually became familiar with abstract terms, we be-came capable of distinguishing mind from body, and of considering the operations of these two substances separately. They then perceived not only what the action of the body is when we say, for example, "I see," but they separately observed the perception of mind and began to regard the term "I see" as being appropriate for both kinds of actions. It is even plausible that this practice came about so naturally that they did not notice the extension of the word's meaning. This shows how a sign which initially was limited to an action of the body became the name of an operation of mind (Essay, 165-166).

46 Justice, Semantics of Form, 36.

47 The most striking English-language case I know is the word injury < Latin iniüria "wrong, hurt, detriment," a nominalization of iniūrius "unjust, wrongful" < in- + iūs, iūr- "right." The extension of Greek trauma "wound" to the psychological aftereffects of a physically wounding event seems the more common direction for things to go.

48 See Genette, Mimologics, 65-66, 155-156, et passim.

49 For some German-language cases (e.g. Bewachung, "act of guarding" > "guardians") see Scott, Accounting. 
the absence of probative evidence I will not insist on it, giving two points to the arrow I draw between Ibn Fāris's first two ușūl:

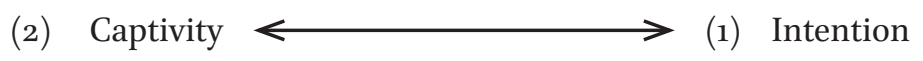

Theoretical though it is, the corporeal-abstract relationship between $\sqrt{ }{ }^{\prime} n w$ and $\sqrt{ }{ }^{\prime} n y$ is easy to understand, and the evidence for it lies as I say on the surface of Classical Arabic tradition. To correlate meanings (2) and (1) with the third semantic aspect of $\sqrt{ }{ }^{n} n w / y$ is harder - the lectio dificilior promised above - but can hardly be avoided, since it is to meaning (3) that Ibn Fāris actually traces al-mána. ${ }^{50}$

\section{$2.4 \quad$ Ostensive ma'nā}

No metaphorical connection between meanings (2) and (1) is made in Maqāyiss al-lugha. The connection Ibn Fāris draws is rather between (1) and (3), and is a metonymic connection, where "the appearance of a thing and its standing forth" (3) are the consequences of "being intent upon a thing" (1). In both meanings, a focus of attention is implied. In meaning (3), however, it is the object of attention that is at issue, or better said: the availability of the object to scrutiny.

In professing a phenomenological basis for al-mánā, Ibn Fāris does not exactly innovate. He gives his source by name: the Kitāb al-'Ayn of al-Khalī b. Ahmad (d. 175/786), where the ma'na of a thing is defined as its mihna, "and the state that its affair comes down to" (wa-ma'nā kulli shay'in mihnatuhu wa-hāluhu lladhi yașîru ilayhi amruhu). ${ }^{51}$ Now for ma'nā to be defined as the state $(h \bar{a} l)$ of a thing is not too surprising (given the circumstantial force of the mașdar mimin form), but for it to be called the mihna of a thing is striking. For the historian of Islam, the word leaps from the page. It names a major turning point in intellectual and religious history, which was the Mu'tazilite Inquisition of the early third/ninth century. I therefore hasten to point out that the Mihna prosecuted from 218/833 to 232/847 during the caliphates of alMa'mūn, al-Mu'tașim, and al-Wāthiq is not implied by the word mịnna in Kitāb al-Ayn. That inquisition — the Mu'tazilite Inquisition — did not begin until some thirty years after the death of al-Layth b. al-Muzaffar (d. ca. 187/803), the lexicographer who brought Kitāb al-Ayn to completion. But mihna as

50 Frank's reading of Ibn Fāris in Meanings, 267-269, does not quite take this in, attributing to him instead an understanding of ma'nā in which intentional meaning (1) is paramount.

$5^{1} \quad$ Kitāb al-'Ayn art. V' $n y$. Ibn Fāris names Kitāb al-'Ayn as his "highest and noblest" source on the first page of Maqāyēs (I, 3). "Comes down to" for yașìru ilā is Frank's translation, in Meanings, 267-268. 
"interrogation" or "inquisition" was known before al-Khalī's day and al-Layth's, as in the remark attributed to the Kufan jurist 'Āmir b. Sharāhịl al-Sha'bī (d. 103/721) in Lisān art. $\sqrt{m}$ h̆n:

Inquisition is an innovation that should be disallowed (al-mihna bid'a). It consists in taking a man by force and subjecting him to a test ( $f a-$ yamtahinuhu), saying "You did this, and you did that," until he confesses to what he has not done, or to [beliefs] it is not lawful to profess.

Of $m a^{\prime} n \bar{a}$ as the phenomenological endpoint of captivity and duress there is much to say ahead. The link between (3) and (1) is drawn by Ibn Fāris as follows:

The third root: In our opinion, the 'unyān of a letter, like its 'unwān ("address"), is best explained as the part that stands out when it is sealed. The ma'nā of a thing has this sense also (min hädhā l-bāb ma'nā l-shay'). Al-Khalīl says no more about it than that "The ma'nā of anything is its predicament (mihnatuhu) and the state that its affair comes down to."

Ibn al-Árābī said: "mā a'rifu ma'nāhu and ma'nātahu [a seldom-heard feminine form] are both said." Linguistic analogy indicates that ma'na is the "aim" that stands out and appears in a thing when it is inquired into. One says: "This is the ma'na of the speech" or "the ma'na of the poem," i.e., that part of an utterance's content that stands forth (alladhiyabruzu min maknūni mà tadammanahu l-lafžu).

Analogical evidence for this is found in an expression of the Arabs: lam ta'ni and lam ta'nu hädhihi l-ardu shay'an are said when the earth produces no vegetation, for in that case it produces nothing of value (lam tufid shay'an), and puts forth no benefit. Confirmation of this is found in the verse (meter: țawill):

Wa-lam yabqa bi-l-Khalșā̉i mimmā 'anat bi-hi min al-baqli illā yabsuhā wa-hajīruhä ${ }^{52}$

At al-Khalșā', there remains no more of what [the land] put forth in the way of green plants, only the husks and the chaff thereof. 
Further confirmation is found in the expression 'anat al-qirba ("The water-skin leaked"), said when its contents flow out of it, as in the verse by al-Mutanakhkhil al-Hudhalī (meter: $\operatorname{sar}^{\prime}$ ):

\section{Ta'nü bi-makhrūtin [la-hu nädihun dhü rayyiqin yaghdhū wa-dhü shalshali]}

It exudes its contents from a puncture [which is dripping and has begun to let its pure contents trickle out. ${ }^{53}$

In this passage, meanings (3) and (1) are represented as two faces of the same event. (1) is an instance of noetic "attention" to an object, and (3) is the phenomenological "disclosure" of that object's hidden content. As a metonymic pair the two meanings substitute for each other easily. Ma'na $\bar{a}$ too is biface: a scene of disclosure and attention to disclosure, independent of the disclosing object's will. The water-skin was not made to leak its contents, after all, but to retain them. What occasions disclosure is a corporeal crisis: the puncture that makes content stand forth, and renders it unto scrutiny by the concerned subject of (1), whose attention it captivates.

The dyad of attention-getting and attention-paying is observable outside of Arabic philology. As a Pragmatist tenet, it was formulated by John Dewey:

Awareness means attention, and attention means a crisis of some sort in an existent situation; a forking of the roads of some material, a tendency to go this way and that. It represents something the matter, something out of gear, or in some way menaced, insecure, problematical and strained. This state of tension, of ambiguous indications, projects and tendencies, is not merely in the "mind," it is nothing merely emotional. It is in the facts of the situation as transitive facts; the emotional or "subjective" disturbance is just a part of the larger disturbance. ${ }^{54}$

This is not to argue for the primacy of ma'na as a "state." The sense in which $m a n \bar{a}$ is said of disclosed content, giving ma'na the appearance of a passive participle, is stronger than any circumstantial meaning left to the word. This is

53 Ibn Fāris, Maqāȳ̄s, IV, 148-149. Ibn Fāris quotes no more than the first two words of this last verse (ta'nū bi-makhrūtin); the rest of it is supplied in Sharh ash'är al-Hudhaliȳin, III, 1250 and Lisān art. $\sqrt{ }$ 'nā.

54 Dewey, Does Reality Possess Practical Character, 138. See also James, Principles, I, 450: "The things we attend to come to us by their own laws. Attention creates no idea; an idea must already be there before we can attend to it." 
what brings ma'nā in line with 'unwān and unyān, which also name the "title" of a book — that is, the language that stands out from it (al-bāriz minhu), signifying the whole of which it is a part. A title is a defining label, functioning either as a literal statement of the book's contents, or as an evocative figure. ${ }^{55}$ For $m a^{\prime}$ 'n $\bar{a}$ to be analogous to this visible share affirms its ostentivity. From out of the background welter of experience, ma'ān $\bar{\imath}$ come at the subject, and so do they come from speech. According to Ibn Fāris, that phenomenological "emergence" is $m a^{\prime} n \bar{a}$ s namesake attribute.

The derivation Ibn Fāris gives for $m a^{\prime} n \bar{a}$ in his other dictionary, the more compact Mujmal al-lugha (Compendium of Lexicography), is simpler than in Maqāyiss al-lugha. In Mujmal, the word is connected to the phenomenological sense of meaning (3) only. ${ }^{56}$ His treatment of the word in al-Săhibib is quite different. In $a l-S a \bar{a} h i b \bar{l}$, all three $u s \underline{u} \bar{l}$ of $\sqrt{ }{ }^{c} n w / y$ are considered in succession as candidates for ma'nä's root, and Ibn Fāris declares disbelief in none of them. The judgment for which he vouches in Maqāyis and Mujmal is relegated in al-Sāhhibì to "Some people say" (wa-qāla qawm). Also in al-Șāḥibı̄ he adduces a locus probans for the word ma'nā: an anonymous pair of basiț-meter verses in which ma'nā is used unmistakably for meaning (2), i.e. the fact or circumstance of captivity and abasement. I will refer to these verses as "the $m a^{\prime} n \bar{a}$-verses" throughout.

The $m a^{\prime} n \bar{a}$-verses are not found outside of philological literature. Their period and provenance are uncertainties, and yet they might be traced to a genre of Arabic literature, and even (as ahead in 3.2) to a particular text. Ibn Fāris's named sources for the verses (discussed at the end of 3.1) go back to the first half of the third/ninth century. Be the historical case what it may, it is for theoretical reasons (treated ahead in section 4) that these verses command the most attention.

The chapter of al-Ṣăhibi in which the verses appear is called "On the meanings of words used to express what is conveyed [through discourse] about

55 Al-Muwațta' (The Well-Trodden [Path]) of Imām Mālik (d. 179/796) is an early Arabic example of the latter; see Schoeler, Genesis, 72.

56 "Anat al-qirba bi-mā'in kathïrin (The water-skin leaked much water) is said if its water is not retained, and becomes visible. From this is the word al-ma'na derived [wa-min hädha shtaqqa l-ma'nā]. 'This is the speech's ma'nā', one says, and 'the ma'nā of the verse.' And feminine form ma'nāh (معناة) is also said." Ibn Fāris, Mujmal, III, 412. 
things" (bāb ma'ānī alfāz al-ibārāt allatì yu'abbaru bi-hā 'an al-ashyā'). The chapter deals with the Arabic vocabulary of hermeneutics:

These fall under three headings: ma'nā, tafsìr, and ta'wïl. Even though they are not the same, the differences in what is meant by them (al-maqāsid bi-hā) are small differences.

Al-ma'nā is an "aim" (al-qașd) and an "object of desire" (al-murād). [Its root verb,] 'anaytu bi-l-kalämi kadhā is said to mean: "My aim (qașadtu) in speaking was ..." or "I endeavored ('amadtu) to say ..."

Al-Qațāan (d. 345/956) recited these verses to me on the authority of Tha'lab (d. 291/904), who heard them from Ibn al-A'rābī:

Mithlu l-burāmi ghadāfì uṣdatin khalaqin lam yasta in wa-hawāmì l-mawti taghshāhu

farrajtu 'anhu bi-șar'aynā li-armalatin wa-bā'isinjā̄a mánāhu ka-ma'nāhu

Left like a tick in a worn-out undershirt, unshaved, with the hoverers of death closing in -

I ransomed him with two of our droves [kept in reserve] for the widow and [any] wretch who should come along with a $m a^{\prime} n \bar{a}$ like his.

This was said of a man presented for execution, whom the poet ransomed with two flocks of livestock, [saying:] "I had them at the ready for any widow who should come asking, or for a wretch like this one [now] brought forth to be killed." Ma'nāhu ka-ma'nāhu means that their intentions (maqșidahumā) in suppliance and abasement are the same. Al-ma'nā could also be one's "state" (al-hăal), in which case [ma'nāhu kama'nāhu means]: "anyone in the same state as he."

Some say al-ma'nā derives from [the idea of] "exposure" (al-izhārr), as when Anat al-qirba is said when the waterskin does not retain its water, but causes it to appear. 'Unwān, the word for a book's "title," depends also on this sense. According to others, al-ma'nā is derived from an expression of the Arabs: 'anat al-ard bi-nabātin hasanin ["The land put forth fine herbage"], said of sprouting plants. According to al-Farrā', lam ta'nu biläduna bi-shay'in ["Our country did not put anything forth"] is said if no plants have sprouted. And Ibn al-Sikkit (d. 244/858) reports lam ta'ni, [the jussive] of 'anā ya'nī. If this is the case, then al-ma'na is that thing that is conveyed by utterance (al-shay' alladhi yufiduhu l-lafz), as in the 
saying Lam ta'ni hädhihi l-arḍ, meaning "This land did not put anything forth." 57

\subsection{Emancipation of the 'āni}

The most important theoretical development in al-Ṣăhib̄̄ is Ibn Fāris's introduction of the ma'na-verses, in which ma'na is heard as a word for "state of captivity." This interpretation is dictated by the verses' theme - a recurrent motif of early Arabic poetry representing the emancipation of a victim of live capture after a battlefield defeat. ${ }^{58}$ The Arabic word for such a prisoner is 'a $\bar{n} \bar{\imath}$ (masc. pl. 'unāt, fem. sg. 'äniya, fem. pl. 'awānī), which is the active participle of A.'anā ya'nu and a cognate of ma'nā. To pay the 'ân’s purchase price and set him or her free was the initiation of a vertical relationship called wala in which emancipated and emancipator stood to each other as client and patron and were called each other's mawlā. ${ }^{59}$ Through this transaction, material capital is converted into symbolic capital and perpetuates the emancipator's nobility. Accordingly, it is a topos of self-praise ( fakhr), as in the verse by Imru' al-Qays (meter: tawīl):

Fa-yā rubba makrūbin karartu warāahu wa-'annin fakaktu l-ghulla 'anhu fa-faddānī ${ }^{60}$

Many a man's distress in battle have I relieved, coming [at his foe] from behind.

And many a captive's fetters have I unfastened, and been pledged his life as ransom.

It also features in encomiastics (madh) such as Zuhayr's praise for Harim b. Sinān (meter: basīt):

57 Ibn Fāris, Șāhibīi, 144-145.

58 The captive is no miscreant but a prisoner of war, as discussed by Anthony, Domestic Origins, 579: "A captive's only crime is to have been an opponent of his or her enemies. More importantly, to be a captive (Ar. asir ) does not necessarily subject one to the vagaries of imprisonment but, rather, to the caprices of one's captor." Everywhere glossed as $a s \bar{r} r$, the 'annī might be considered a pre-carceral category: the 'ānī of poetry is typically a bound captive, not necessarily confined indoors.

59 See Forand, Relation of the Slave and the Client, and Crone, Roman, provincial and Islamic law, 49-63.

6o Dīwān Imri' al-Qays, 90; see also 319 (verse 5), and for more examples al-Ṭūsī, Sharh dīwān Labīd, 9 (verse 19) and 251 (verse 83), Dīwān al-Áshāa, 66 (verse 1), and Dīwān al-Sulayk, 91 (verse 3). 
Agharru abyaḍ fayyādun yufakkiku 'an

aydi l-unāti wa-'an a'nāqihā l-ribaqa ${ }^{61}$

His face blazes with nobility. He overflows [with generosity]. He unfastens manacles from the hands of captives, and from around their necks.

In a ghazal of 'Umar b. Abī Rabī'a (d. 93/712 or 103/721), the trope is heard to parodic effect (meter: basit $)$ :

\section{Yā Umma Nawfala fukkī 'āniyan mathalat}

bi-hi Quraybatu aw huwa hālikun 'ajală ${ }^{62}$

O Umm Nawfal, set the captive free - and hurry,

[before] he perishes, or Qurayba turns him into a gelding!

The $m a^{i} n \bar{a}$-verses therefore participate in a well-established convention of representing the scene of a captive's emancipation. Conventional too is their pairing of captive and widow, found together in Mutammim b. Nuwayra's elegy for his brother Mālik, who was killed in the Ridda wars of Islam's first decade (meter: tawill):

Wa-li-l-sharbifa-abkī Mālikan wa-li-buhmatin shadīdin nawāhīhā 'alā man tashajja ă ${ }^{63}$ wa-dayfin idhā arghā țurūqan baìrahu wa-'ānin thawā fì l-qiddi hattā takanna'ā

wa-armalatin tamshī bi-ash'atha muhthalin ka-farkhi l-ḥubārā ra'suhu qad taḍawwa'ā. ${ }^{64}$

On behalf of wine-drinkers [everywhere], I weep for Mālik, and on behalf of the armed men [he leaves behind],

who are violent and vigilant against all comers;

\footnotetext{
61 Tha'lab, Sharh Shir Zuhayr, 49.

62 Sharh Dīwān 'Umar, 350.

63 In al-Dabbī's al-Mufaddaliyyāt, this verse appears with nawāhīhu; in the philological sources (Lisān and Tāj arts. $\sqrt{b h m}$ ) it is adduced with nawāhịh $\bar{a}$. In either case the pronoun's referent is buhma, which may be taken as a masculine singular noun meaning "a man who is courageous in battle," or a feminine singular noun meaning a "band of armed men." The latter reading is the one followed here.

64 Ḍabbī, Mufaḍdaliyyāt, 622 (no. 67, verses 12-14).
} 
and of the [would-be] guest who sets his camel bawling, in request of shelter for the night;

and of the captive whose leather bonds have shrunk, so long have they lain upon him;

and of the widow who walks with her unkempt, malnourished [child]

like a bustard chick whose head is crowned with branching shocks.

Only in relation to these and other instances of the emancipation motif can the specific features of the $m a^{\prime} n \bar{a}$-verses be appreciated. One thing we find by comparison is that they are distinguished for their description of the captive's abject state (not as graphic as Mutammim's, but vivid nonetheless). They also have an element of suspense we do not find in the other examples. Not until the second verse do we learn the fate of the wretched individual described in the first.

There is additionally a variant of the first $m a^{\prime} n \bar{a}$-verse in which the captive is shown pleading with his captors. Thus it was adduced by the lexicographer alJawharī (d. ca. 398/1007-8), in illustration of the verb sa'ala yas'alu's "lightened" form $(\operatorname{takhfif}): 65$

Al-Akhfash (the Younger, d. 315/927) said: [...] The hamza may be lightened, rendering the verb sâla yasālu, as in the verse:

\section{Wa-murhaqin sāla imtāáan bi-ușdatihi lam yasta'in wa-hawāmì l-mawti taghshāhu}

Ah, the poor blighter who begged to keep his undershirt, unshaved, with the hoverers of death closing in...

The ma'n $\bar{a}$-verses are distinguished for their efflorescence of rare words: murhaq "blighter," ușda "undershirt," ista'āna "to shave one's pubes," hawāmì "hoverers," and șar "drove of camels." 66 To these the verses owe their place in the Arabic lexicographical record, as summarized in Table $4 .{ }^{67}$ Perhaps the most salient facts in this table are that Ibn Fāris is the only authority to adduce

65 Jawharī, Șịnạh (art. $\left.\sqrt{ } s^{\prime} l\right)$, v, 1723 . Table 4 will show which version is cited by each authority and in what context.

66 The lightenings of sāla and metathesis of hawāmì (< hawā̇im) are both for the sake of meter (bi-l-darüra). For șar' the reading șir' is general.

67 My summary builds on the work of Ya'qūb, al-Mujam al-mufașal, 291-292. 
the $m a^{i} n \bar{a}$-verses in illustration of the word $m a^{i} n \bar{a}$, and that only in al-Săhibi does it happen. ${ }^{68}$

TABLE 4 Documented occurrences of the ma'nā-verses

\begin{tabular}{|c|c|c|c|c|}
\hline \multicolumn{2}{|c|}{ Source text } & Lemma & Version & Isnād \\
\hline \multicolumn{2}{|c|}{$\begin{array}{l}\text { al-Zajjājī, } \\
\text { Akhbār al-Zajjājī }\end{array}$} & $\mathrm{N} / \mathrm{A}$ & $\begin{array}{l}\text { Both verses, with } \\
\text { mithlu }\end{array}$ & $\begin{array}{l}\text { al-Akhfash the Younger < } \\
\text { Tha'lab < Ibn al-A'rābī }\end{array}$ \\
\hline \multirow{3}{*}{\multicolumn{2}{|c|}{$\begin{array}{l}\text { al-Azharī, } \\
\text { Tahdhīb al-lugha }\end{array}$}} & $\sqrt{s} r^{c}$ & $\begin{array}{l}\text { Both verses, with } \\
\text { mithlu }\end{array}$ & Ibn al-A'rābī \\
\hline & & $\sqrt{{ }^{c} w n}$ & $\begin{array}{l}\text { 1st verse only, with } \\
\text { mithlu }\end{array}$ & Tha'lab < Ibn al-A'rābī \\
\hline & & $\sqrt{w s s ̦ d}$ & $\begin{array}{l}\text { 1st verse only, with } \\
\text { mithlu }\end{array}$ & Thalab \\
\hline \multicolumn{2}{|c|}{$\begin{array}{l}\text { al-Khațțābī, } \\
\text { Gharīb al-ḥadīth }\end{array}$} & $\mathrm{N} / \mathrm{A}$ & $\begin{array}{l}\text { Both verses, with } \\
\text { mithlu }\end{array}$ & $\begin{array}{l}\text { Ghulām Tha'lab < Tha'lab } \\
<\text { Ibn al-A'rābī }\end{array}$ \\
\hline \multirow{2}{*}{\multicolumn{2}{|c|}{$\begin{array}{l}\text { al-Jawharī, } \\
\text { al-Șihāạh }\end{array}$}} & $\sqrt{ }{ }^{\prime} s \underline{s}$ & $\begin{array}{l}\text { 1st verse only, with } \\
\text { murhaq }\end{array}$ & Unattributed \\
\hline & & $\sqrt{s^{\prime} l}$ & $\begin{array}{l}\text { 1st verse only, with } \\
\text { murhaq }\end{array}$ & al-Akhfash \\
\hline \multirow{3}{*}{$\begin{array}{l}\text { Ibn } \\
\text { Fāris }\end{array}$} & Maqāyīs & $\sqrt{s} r^{c}$ & 2nd verse only & Unattributed \\
\hline & Mujmal & $\sqrt{{ }^{\prime}} \bar{a} n$ & $\begin{array}{l}\text { Both verses, with } \\
\text { murhaq }\end{array}$ & Unattributed \\
\hline & al-Ṣāḥibī & $\mathrm{N} / \mathrm{A}$ & $\begin{array}{l}\text { Both verses, with } \\
\text { mithlu }\end{array}$ & $\begin{array}{l}\text { al-Qatțān < Tha'lab } \\
\text { < Ibn al-A'rābī }\end{array}$ \\
\hline
\end{tabular}

68 As Table 4 shows, Ibn Fāris quotes the ma'nā-verses once in Mujmal and once in Maqāȳ̄s, and in neither case is it in connection with $\sqrt{ }{ }^{\prime} n w / y$. Similarly, Lisān quotes the verses in six different entries, and $T a \bar{j} j$ in five, but in their entries for $\sqrt{ }{ }^{\prime} n w / y$ the verses do not appear. 
TABLE 4 Documented occurrences of the ma'nā-verses (cont.)

\begin{tabular}{|c|c|c|c|}
\hline Source text & Lemma & Version & Isnād \\
\hline \multirow[t]{2}{*}{$\begin{array}{l}\text { Ibn Sīda, } \\
\text { al-Muḥkam }\end{array}$} & $\sqrt{h} m w$ & $\begin{array}{l}\text { 1st verse only, with } \\
\text { murhaq }\end{array}$ & Ibn al-Sikkīt \\
\hline & $\sqrt{w} w \underset{d}{ }$ & $\begin{array}{l}\text { 1st verse only, with } \\
\text { murhaq }\end{array}$ & Ibn al-Sikkīt \\
\hline \multirow[t]{8}{*}{$\begin{array}{l}\text { Ibn Manẓūr, } \\
\text { Lisān al-'arab }\end{array}$} & $\sqrt{ }{ }^{\prime} s ̣$ & $\begin{array}{l}\text { 1st verse only, with } \\
\text { mithlu }\end{array}$ & Thalab \\
\hline & & $\begin{array}{l}\text { Alt. 1st verse with } \\
\text { murhaq }\end{array}$ & Unattributed \\
\hline & $\sqrt{h} m \bar{a}$ & $\begin{array}{l}\text { 1st verse only, with } \\
\text { murhaq }\end{array}$ & Ibn al-Sikkīt \\
\hline & $\sqrt{r h q}$ & $\begin{array}{l}\text { Both verses, with } \\
\text { murhaq }\end{array}$ & $\begin{array}{l}\text { Ibn Barrī < "Abū 'Alī al-Bāhilī } \\
\text { Ghayth b. 'Abd al-Karīm" }\end{array}$ \\
\hline & $\sqrt{s^{\prime} l}$ & $\begin{array}{l}\text { 1st verse only, with } \\
\text { murhaq }\end{array}$ & al-Akhfash (as in al-Şihāhh) \\
\hline & $\sqrt{s} r^{c}$ & $\begin{array}{l}\text { Both verses, with } \\
\text { mithlu }\end{array}$ & Ibn al-A'rābī \\
\hline & & $\begin{array}{l}\text { Alt. 1st verse with } \\
\text { murhaq }\end{array}$ & Ibn Barrī < al-Shaybānī \\
\hline & $\sqrt{ } w n$ & $\begin{array}{l}\text { 1st verse only, with } \\
\text { mithlu }\end{array}$ & Ibn al-A'rābī \\
\hline
\end{tabular}


TABLE 4 Documented occurrences of the ma'nā-verses (cont.)

\begin{tabular}{|c|c|c|c|}
\hline Source text & Lemma & Version & Isnād \\
\hline \multirow[t]{9}{*}{$\begin{array}{l}\text { al-Zubaydī, } \\
\text { Tājal-'arūs }\end{array}$} & $\sqrt{ }$ 'șd & $\begin{array}{l}\text { 1st verse only, with } \\
\text { murhaq }\end{array}$ & Unattributed \\
\hline & $\sqrt{w s s} d$ & $\begin{array}{l}\text { 1st verse only, with } \\
\text { murhaq }\end{array}$ & Ibn Sīda $<$ Ibn al-Sikkīt \\
\hline & $\sqrt{s} r^{c}$ & $\begin{array}{l}\text { Both verses, with } \\
\text { mithlu }\end{array}$ & Ibn al-A'rābī \\
\hline & & $\begin{array}{l}\text { 1st verse with mithlu, } \\
\text { and buzāti for burāmi }\end{array}$ & $\begin{array}{l}\text { "A likely case of tahrif" in } \\
\text { al-Ubāb al-zākhir of } \\
\text { al-Ṣaghānī }\end{array}$ \\
\hline & & $\begin{array}{l}\text { Alt. 1st verse with } \\
\text { murhaq }\end{array}$ & Ibn Barrī < al-Shaybān̄̄ \\
\hline & $\sqrt{r h q}$ & $\begin{array}{l}\text { Both verses, with } \\
\text { murhaq }\end{array}$ & $\begin{array}{l}\text { al-Ṣaghānī; Ibn Barrī < "Abū 'Alī } \\
\text { al-Bāhilī Ghayth b. 'Abd } \\
\text { al-Karīm" }\end{array}$ \\
\hline & & $\begin{array}{l}\text { Alt. 1st verse with } \\
\text { mithlu }\end{array}$ & $\begin{array}{l}\text { Ghulām Tha'lab in } \\
\text { al-Yawāqüt fì l-lugha }\end{array}$ \\
\hline & $\sqrt{s^{\prime} l}$ & $\begin{array}{l}\text { 1st verse only, with } \\
\text { murhaq }\end{array}$ & Unattributed \\
\hline & $\sqrt{ } w n$ & $\begin{array}{l}\text { 1st verse only, with } \\
\text { mithlu }\end{array}$ & Ibn al-A'rābī \\
\hline
\end{tabular}


An originary context for the $m a^{\prime} n \bar{a}$-verses seems irrecuperable. Their tale begins in medias res, which might suggest an extract from a longer qașida, though their theme is conventional enough to be able tell what's going on. The main obscuring factor is the verses' avoidance of the word 'āni, which is the lexical marker in every other instance of the emancipation theme. The captive is not called "captive," here, but "wretch" and "blighter"; in 'ānıs place, the cognate ma'nā denotes the wretch's "state of captivity." As such, the verses are both formulaic and formula-avoidant, as if composed with mannerist aims of creative variation on the theme.

The names and death-dates of the ma'nä-verses' known transmitters are arranged in Table 5. From this stemma, the most important thing to point out is that the verses were transmitted overwhelmingly by Kufan scholars and students of the Kufan tradition in Arabic grammar. With regards to Ibn Fāris (called Kuferfreundlich by Gotthold Weil) this is no great surprise. ${ }^{69}$ Where it might have bearing is on the probative value of the verses themselves if, that is, any weight is given to a typically "Basran" critique of the Kufan school. Now the actual terms of the third/ninth century Basra-Kufa divide are notoriously hard to make out from the latter-day representations of al-Zajjājī (d. 337/948) and Abū l-Bakarāt b. al-Anbārī (d. 577/1181), and alMubarrad too (d. 286/900) is an unsure guide. ${ }^{70}$ Typically it is remembered as an opposition between analogy and anomaly. The stereotype of the Basran position is that it put enormous trust in the analogically-derived principles (ușu $l)$ of Arabic grammar, to the point of excluding linguistic evidence that contravened them; Kufans meanwhile are remembered for their readiness to modify the ușül on the basis of rare and anomalous usage. Michael G. Carter shows in a persuasive 1999 article that the divide began with a difference over the admissibility of new data in grammatical debate. ${ }^{71}$ The practice of deriving the principles of grammar from newly assembled literary and discursive evidence was called istigra $\vec{a}^{\prime}$ (induction), and in the second/eighth and third/ ninth centuries both Basrans and Kufans did it as a matter of course. But when, some time later in the third/ninth century, the philologists of Basra began to close the door on new evidence, the Kufans kept it open, continuing to expand the poetic corpus, even if it meant arguing over already-formalized principles anew.

69 Weil, Die Grammatischen Schulen, 181.

70 See Baalbaki, Arab Grammatical Controversies.

71 See Carter, Struggle for Authority. 
TABLE 5 The $m a^{\prime} n \bar{a}$-verses in lexicographical literature: a stemma of isnāds from Lisān, et alibi

Ibn al-A'rābī

(d. 231/846)

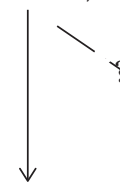

Tha'lab

(d. 291/904)<smiles>CCCCCCCC</smiles>

Ibn al-Sikkīt

(d. $\left.244 / 85^{8}\right)$
Abū 'Amr al-Shaybānī

(d. ca. 210/825)

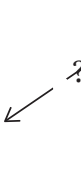

al-Akhfash al-Aṣghar

(d. 315/927)

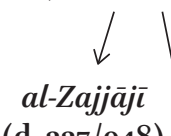

(d. 337/948)
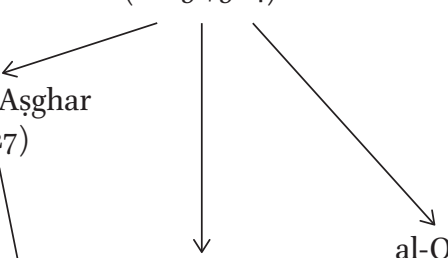

al-Qațțān

(d. 345/956)

(d. 345/957)

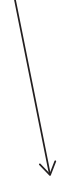

al-Jawharī

(d. ca. 398/1007)

\section{al-Khațtāà}

(d. 388/988) )

\section{Ibn Färis}

(d. 395/1004)
"Abū 'Alī al-Bāhilī

Ghayth b.

'Abd al-Karīm"

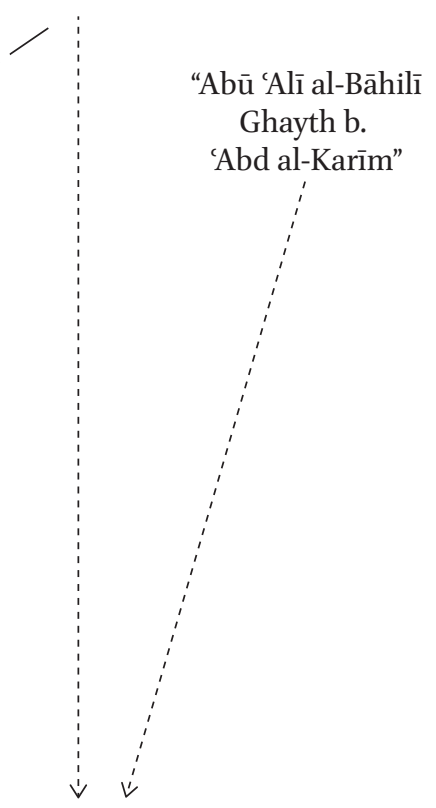

Ibn Barrī

(d. 582/1187)

Names in bold italics indicate extant sources (as named in Table 4). Solid arrows indicate direct transmission, and dotted arrows are for textual transmission. Ibn al-Sikkit is named as a source in the Muhkam of Ibn Sīda (d. 458/1066); in his extant works the verses are not found.

I bring all this up by way of conceding that the probative value of the ma'n $\bar{a}$ verses lies part-way open to Basran-spirited critique. I will also concede that the verses' earliest-known transmitters were excoriated for their credulity (and worse) by contemporary Basrans and the inheritors of their school. ${ }^{72}$ If I call these "concessions" it's not because they carry much weight with me personally,

72 See Bayān, IV, 24, for a low estimation of al-Shaybānī's acumen by al-Jāhịiz. Concerning Ibn al-A'rābī, the following remembrances are preserved by Abū l-Ṭayyib al-Lughawī (Marātib al-naḥwiyyīn, 92):

He transmitted the teachings of Basran scholars — particularly Abū Zayd [al-Anșārī], although he never studied with him. In addition to Abū Zayd, he had a number of Bedouin informants like al-Ṣaqīl, Ujruma, Abū l-Makārim, as well as some that did not meet the standards of the Basran scholars.... One inveterate detractor of Ibn al-Árābī 
but to show that my enthusiasm for the ma'nā-verses is not uncritical nor uninformed. I make no claim for the verses' antiquity; quite obviously they postdate the work of 'Antara and Zuhayr. Just how late they are I decline to speculate, beyond pointing out their terminus ante quem in the careers of $\mathrm{Abu}$ 'Amr al-Shaybānī (d. 213/828) and Muḥammad b. Ziyād al-A'rābī (d. 231/846). If the $m a^{\text {in }} \bar{a}$-verses were transmitted by Kufan scholars only, it would suffice me as classical provenance.

\subsection{Abyātal-ma ān̄̄}

There is also however a Basran filament to the stemma. In Lisān art. $\sqrt{r h q}$ we find the man $\bar{a}$-verses quoted with the following isnād and commentary:

Ibn Barrī (d. 582/1187) said: This was attested by Abū 'Alī al-Bāhilī Ghayth b. 'Abd al-Karīm, who attributed it to one of the desert Arabs (li-ba'd al'arab). [The poet] describes a nobleman carried off the field of battle, who asks that they not begrudge him his $u s ̦ d a$, which is a small garment worn beneath the other garments. In other words, [he asks] that he not be stripped. "Unshaved" (lam yastain) means that he has not shaved his pubes ('ānatahu). The man is on the point of death. [Where the poet says] "I ransomed him with two of our droves" (farrajtu 'anhu bi-șar'aynā), the "two droves" are units of camel: one you dispatch [to the water-source] when you bring the other camels back, due to their great numbers. He says: "I ransomed him with two droves of camel, exchanging them for his manumission. It was for the sake of widows and orphans that I had these droves at the ready." ${ }^{3}$

Abū 'Alī al-Bāhilī Ghayth b. 'Abd al-Karīm is a hard man to locate. Outside of Lisān art. $\sqrt{r h q}$, I find the name in a few places only. One is Tärïkh madinat Dimashq of Ibn 'Asākir (d. 571/1176), where he is the source for a single khabar (IV, 229): "Ghayth b. 'Abd al-Karīm al-Bāhilī Abū l-Ḥasan (sic) said: The

was Abū Nașr al-Bāhilī (!), who called him a liar and accused him of tazayyud (forgery or embellishment) and discounted his authority.

For more on Abū Nașr (whose quarrels with Ibn al-A'rābī are the only well-documented thing about him) see just ahead.

73 Qāla Ibn Barrī: Anshadahu Abū 'Alī al-Bāhilī Ghayth b. 'Abd al-Karìm li-ba'd al-'arab yasifu rajulan sharīfan irtaththa fì ba'd al-ma'ārikfa-sa'alahum an yumti'ūhu bi-ușdatihi, wa-hiya thawb șaghīryulbasu taḥta l-thiyāb, ay lā yuslabu. Wa-qawluhu "lam yasta in": lam yahliqu 'ānatahu. Wa-huwa fi hạl al-mawt. Wa-qawluhu "farrajtu 'anhu bi-șar'aynā": al-șar'āni al-ibilāni taruddu ịhdāhumā hịna tașduru l-ukhrā li-kathratihā. Yaqūlu: Iftadaytuhu bi-șar'ayni min al-ibil fa-a'taqtuhu bi-himā, wa-innamāa a'dadtuhumā li-l-arāmil wal-aytām afdīhim bi-hā. 
Prophet, God's blessings and peace be upon him, had five horses: Lizāz, Liḥāf, alMurtajir, al-Sakb, and al-Yasūb." Another is in the onomastic register of Ibn Mākūlā (d. 475/1082), al-Ikmāl fì raf' al-irtiyāb (VII, 41), where we find: "Ghayth b. 'Abd al-Karīm al-Bāhilī: compiler of a book of ma'ānī al-shi'r based on the teachings of al-Așma'î."

With that, "Ghayth b. 'Abd al-Karīm al-Bāhilī" is an evident misnomer for the philologist Abū Nașr Aḥmad b. Ḥātim al-Bāhilī (d. 231/855). Abū Nașr was a student of al-Așma'ì, a transmitter of his works, and was called by some Ghulām al-Așma‘̄ ("al-Așmaîi's amanuensis"). ${ }^{74}$ How and why his work would be given out in the fifth/eleventh century as one Ghayth's I have no idea. Yāqūt (d. 626/1229) and al-Qifțī (d. 646/1248) knew Abū Nașr to be the author of Kitāb Abyāt al-ma'ānī, and so did Ibn al-Nadīm (d. 385/995), who mentions two commentaries on it: a Kitāb Sharh Kitāb al-Ma ānī li-l-Bāhilī by Lughda al-Iṣfahānī, and Kitāb Sharh Ma āñ̄ al-Bāhilī al-Anșārī by Bundār b. 'Abd alḤamīd b. Lizza (or Lurra) al-Karajī al-Ișfahānī (both fl. mid-third/ninth c.). ${ }^{75}$ Nine other titles are attributed to him by Ibn al-Nadīm, but it is for Kitāb Abyāt al-ma'ānì that Abū Nașr is best remembered — to the point that, as Jarīî̀ Salīm al-Manșūrī Thubaytī says in his survey of the genre, "Al-Bāhilī's name is hardly ever mentioned without the accompanying phrase șāhib Kitāb al-Ma ānī."76

Ma'āni, the plural of ma'nāa, is conspicuous in these titles. In poetry criticism, ma' $n \bar{a}$ was used for the "poetic theme" embodied in a given verse, as well as for the "meaning" of a particular verse or phrase or word. Then there was a genre of poetry anthology called abyāt al-ma'ānì ("verses of [ambiguous or puzzling] meanings"). The contents of ma'āni anthologies were selected for their obscurity, and were supplemented with clarifying commentary. Kitāb al-Ma'āni al-kabìr of Ibn Qutayba (d. 276/889) is the major extant example, and the Ma'ānī al-shi'r of al-Ushnāndānī (d. 288/901) is another. ${ }^{77}$ Abū Nașr's Kitāb Abyāt al-ma'ānì was an earlier member of the genre, as attested by numerous outtakes in the literature at large. A good number may be found in Lisān, where they were imported mostly from Tahdhïb al-lugha of al-Azharī (d. 370/981). Twenty-four fragments are attested in Hilyat al-muhädara, the poetry anthology of Ibn al-Muẓaffar al-Ḥātimī (d. 388/998), and still more are strewn throughout tradition as disjecta membra.

74 See Hämeen-Anttila, Al-Așma'ī. The most thorough modern study of Abū Naṣr is by 'Abd al-Quddūs Abū Ṣālị and is included in his introduction to Dīwān Dhī l-Rumma, I, 83-113.

75 Yāqūt, Mujam al-udabā', I, 227; Qifțī, Inbāh al-ruwāt, I, 71; Ibn al-Nadīm, Fihrist, 88, 130, 133 .

76 Thubaytī, Abyāt al-ma'ānī, 46 .

77 See Orfali, Sketch Map, 44-45, in particular 45, n71 for relevant observations on the abyāt al-ma'ānī genre by al-Jurjānī and al-Suyūțī. 
To catalogue the surviving attestations of Kitāb Abyāt al-ma'āni is the work of a separate study. ${ }^{78}$ By way of comparison to the mán $\bar{a}$-verses I limit myself to one other excerpt from Abū Nașr's lost work. It is preserved in Tahdhīb allugha art. $\sqrt{r a \bar{q}}$ (IX, 284), and the verses it treats are credited to Dhū l-Rumma (d. 117/735-36). Bibliographically, it is a telling citation, for while Abū Nașr's commentary on Dhū l-Rumma's dīwān is extant to us as a full-length work, we do not find the verses there but in a mulhaq (supplement) of attributed fragments appended to Dīwān Dhì l-Rumma by its modern editor. ${ }^{79}$ Their connection to Abū Nașr from outside this commentary argues strongly for their belonging to Kitāb Abyāt al-ma'ānī, even though the title happens not to be mentioned here:

The rawq of a tent is the same as its riwa a , and that is the drape of cloth (shuqqa) below the cloth at the top [of the tent's entrance], as in the verses by Dhū l-Rumma (meter: țawīl):

Wa-mayyitatin fì l-ardi illā ḥushāshatan thanaytu bi-hā hayyan bi-maysūri arba'i

bi-thantayni in tadrib dhihi tanșarif dhihi ${ }^{80}$ li-kiltayhimā rawqun ilā janbi mukhda i

Many's the dying [mark stamped] in the earth, little more than a wisp, that I have matched to the living [camel] by the sinister edge of [one of] its four [pads],

through the two furrows [of my eyes]. Each turns to what the other hits upon.

The "drapes" of each are thrown wide of its recess.

Al-Bāhilī said: The "dying" thing (mayyita) he means is the brand (uthra) which he matches to the living camel. The poet says: "I followed its prints, until it was [found and] returned to the herd." Al-uthra is a branding-mark lain on the pad of a camel's foot, said here to be "dying" because it is faint and leaves no clear mark. This is when [the brand] has become ingrown

78 Larsen, Towards a reconstruction.

79 Dīwān Dhī l-Rumma, III, 1888-1889. This commentary is Abū Nașr's only work in print. The survival of his Ishtiqāq al-asma $\bar{a}^{\prime}$, in manuscript at the Süleymaniye Library (MS Esad Efendi 2357) is also noted by the editor (I, 97).

8o Thus in Lisān art. $\sqrt{r} w q$; Ibn Qutayba's Kitāb al-Ma'ānī al-kabīr, III, 1188, where these verses also appear, has in tașrif dhihi tanșarif dhihi ("Where one [eye] turns, there turns the other"). 
and is nearly level with the pad, until such time as it is renewed except for one remnant along a "sinister edge" (bi-maysür), that is, the left side [of one pad]. The poet's meaning is that he recognized [the camel's footprint] from a single left-hand edge.

By thaniyyatayni ("two furrows") is meant "two eyes." 81 Rawq is the same as riwā [and here it refers to]: the bones of the brow, due to their projection over the eye. By mukhda' is meant the inward part of the eye.

Both the verses and their commentary compare to the ma'n $\bar{a}$-verses and Lisān art. $\sqrt{r} h q$ 's commentary in a number of ways. Almost nothing in them is named openly: in place of ordinary names for things are substituted rare vocabulary and non-conventional epithets and metaphors. Once decoded, the underlying themes turn out to be conventional: in both examples, the theme is self-praise. The commentary in each is for the most part lexical, but also narrative: it restates the meaning of the verse in plainer language and fills in its ellipses, so as to make the verse make sense and tell more of a story.

The ma'nā-verses' strong resemblance to these and other attestations of al-Bāhilī leads me to hypothesize that the ma'nā-verses once featured in his Kitāb Abyāt al-ma'ānī. If correct, this hypothesis dictates a new hermeneutic for the ma'nā-verses. Viewed as abyāt al-ma'ānī, their rare lexemes (murhaq, $u s \underline{d a}$, șar' and the rest) present as generic features. Also explained is the $m a^{\prime} n \bar{a}-$ verses' avoidance of the word 'anni, which would give away the "emancipation of the captive" theme on a first hearing or reading. Indeed, tracing the ma ' $n \bar{a}-$ verses to Kitāb Abyātal-ma'ānī changes most of the literary-historical questions we might ask of them. The point is no longer to fit the verses to a particular period or style of poetry, but to a genre of scholarship. The question of the verses' place in a longer poem falls away completely.

The ambiguity of the mán $\bar{a}$-verses hinges on more than just vocabulary. Their central enigma is the identity of the third-person masculine singular pronoun - the - hu of manāhu - and the nature of the predicament he is in. These at any rate are the questions that the commentary of Lisān art. $\sqrt{r} h q$ answers first: "[The poet] describes a nobleman carried off the field of battle." Meanwhile, the meanings of mána $\bar{i}$ itself are left unaddressed. The word's place in the verse is plainly that of a cognate substitute for the expected term 'anni. But the theoretical specifics of $m a^{\prime} n \bar{a}^{\prime}$ ' meaning here were evidently beside the point for every commentator on the mánā-verses beside Ibn Fāris.

81 Here, by restoring the $y \bar{a}^{\prime}$ to thaniyyatayni, the commentary makes note of the verse's rough license-taking (darüra), through which the word was shortened to thantayni in order to fit the meter. 


\section{$4 \quad$ Meaning and Captivity}

Not all great literature is major literature, and the $m a^{i} n \bar{a}$-verses are as minor as they come. The abyāt al-ma'āni genre might be described as minor also, albeit fruitful and well-loved. ${ }^{82}$ It is a semi-didactic genre whose purpose is to instruct and entertain, and (like all puzzles) the pleasure it brings comes in flashes. Assuredly the genre is worthy of serious study, but I do not think its own terms (i.e., the stated concerns of the compiler-commenter) need be adhered to strictly. It may be that I see more in the $m a^{\prime} n \bar{a}$-verses than Abū Nașr intended, though scarcely more than Ibn Fāris who was the first to hold them up and invite the question: what makes it possible for ma'na to be used as a word for "captivity"? My answer to the question is once again that the verb for seizure of attention (1) shares a root with the verb for surrender of physical autonomy (2), and that their meanings are metaphorically coordinated even as the verbs find formal isomorphy in $m a{ }^{\prime} n \bar{a}$, their common verbal noun. And so too has the overlap between a psychological seizure of attention (1) and a phenomenological disclosure of contents (3) - the connection that Ibn Fāris himself draws through mañ - been discussed.

It remains to put them all together. There is a figure into which the different reflexes of $\sqrt{ }{ }^{c} n w / y$ may be assembled without strain. The figure is not predetermined by any particular commitment to Charles Sanders Peirce or the ancient Stoics or any other theorist of a tripartite sign. There is just no way of connecting three ideas in graphic space, other than with a triangle:

(1) Intention
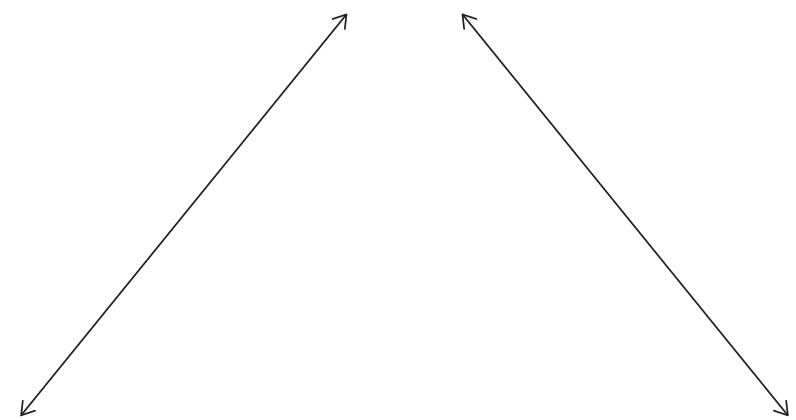

(2) Captivity

(3) Disclosure

82 Thubaytī, Abyāt al-ma'ānī, 44-54, builds on Sezgin's catalogue (GAS II, 57-60), listing eight titles of ma'ānī works predating Abū Nașr's and upwards of two dozen by his contemporaries and later authors. 
It will be noticed that the arrow from (2) to (3) is the only one without two pointed heads. This is because the connection I propose between (2) and (3) is not bi-directional. It is an instrumental and causal connection - a metonymic connection - and at that, I do believe meaning (3) and its forms to be derivative. My belief in the notional priority of meaning (2) over (1) has already been aired, on the debatable grounds that ethical and psychological concepts derive metaphorically from bodily experience (the way Latinate emancipation is to take someone out of someone else's grasp, and concept is what the mind has a grasp of). ${ }^{83}$ But while the priority of (2) to (1) cannot be proven (and hence the arrow's two heads), the connection between (2) and (3) goes just one way, and that way goes through mihna.

In Kitāb al-Ayn art. $\sqrt{ }^{\prime} n y, m a^{\prime} n \bar{a}$ was defined as "the mihnna of any thing" (ma'nā kulli shay'in mihnatuhu). The equivalence is restated in Kitāb al-Ayn art. $\sqrt{m h n}$ :

Mihna is the ma'na of speech that undergoes a test (yumtahanu) in order that [the speaker's] inner thoughts be known. [Its affiliated verb is of the VIII ${ }^{\text {th }}$ form. One says:] imtahantuhu ("I put him to a test") and imtahantu l-kalimata ("I put his speech to a test"), i.e., "I looked into what it came down to" (nazartu ilā mā yașìru șayruhu). The Harūriyya sect imposed a mihna such that whoever failed it was killed, and whoever passed it was allowed to persist in error. ${ }^{84}$

The minna is a trial through which a subject's inner thoughts are revealed, and here it seems to name the results of such a trial. If not the outcome of a process of exposure, al-mihna is the process itself. Where Kitāb al-'Ayn equates it to al$m a^{\prime} n \bar{a}$, such that the mihna of a thing is its $m a^{\prime} n \bar{a}$ and the $m a^{\prime} n \bar{a}$ of discourse is its mihna, we see Ibn Fāris's basis for opining that the word ma'nā derives from (3)'s meaning of visibility and exposure. Although he does not dwell on mihna as a scene of detention and coerced confession, meaning (2) does enter Ibn Fāris's gloss where he says: "Ma'nāhu ka-ma'nāhu means that their

83 No mind-hand metaphor comes built into Arabic the way it is with the Latinate concept, whose place in Arabic is occupied by ma'nā and ma'qül ("intelligible," connected also to a verb of binding and restraint). In medieval Latin, ma'nā coexisted with conceptus after it was imported as intentio, as discussed by de Libera, Intention, 504; cf. Gyekye, The Terms 'Prima Intentio' and 'Secunda Intentio', and Black, Intentionality in Medieval Arabic Philosophy.

84 Al-mihnna ma'nā l-kalām alladhì yumtahanu fa-yu'rafu bi-kalāmihi ḍamìru qalbihi, waimtahantuhu wa-imtahantu l-kalimata, ay nazartu ilā mā yașīru șayruhu wa-fì șifat alharüriyya la-hum mihnnatun man akhța'ahā qatalathu wa-man așābahu aḍallathu. 
intentions in suppliance and abasement are the same" (ay inna maqșidahumā fíl-su'äl wa-l-bu's maqșid wähid). The degradation of the captive comes not just through description, but is built into the very topos of the 'annī, as it is in the experience of bound captivity: suppliance and abasement are structural features of the role. Sūrat T⿱a $\bar{a} H \bar{a}$ (Q 20:111) itself seems to be recollected in the ma'nāverses' narration of the scene, as before the reckoners of his fate the 'ann $\bar{\imath}$ is brought low.

Brought low, and made visible. In the variant of the first verse (with murhaq), the captive begs to keep his clothes. His fate is subject to a deliberative process - not by a judge, but by his vanquishers in battle. The 'anni is objectified and exposed to view, giving us ma'na in the ostensive aspects of meaning (3): the scene of something's coming to light under duress. This at any rate is how I interpret the milnna-ma'nā pairing in Kitāb al-'Ayn. ${ }^{85}$

The connection between (2) and (3) clarifies the relationship of both to meaning (1). The captive's interiorized ma'na - his "intention" in the situation - is not formulated in response to his predicament, is but coterminous with it. Mán $\bar{a}(1)$ is the noetic corollary of a bodily state (2), and the way it is disclosed is only partly through speech. There may be a verb of speaking $\left(s \bar{a} l a<s a^{\prime} a l a\right)$ in the variant to the first verse, but whatever the captive's words, they are ancillary to the Gestalt taken in by his captors. The ma'na in question is his, and not ma'nā kalāmihi (the meaning of his discourse). To all who behold the captive, his needs are known; they are, again, structural features of his predicament, revealed under duress. ${ }^{86}$

\subsection{Phenomenon and Sign}

Perhaps it is strange to say so much about meaning without talking about the sign. Then again, how is semiosis at work in the ma'nā-verses? To begin to answer, it is necessary at last to recall Charles Sanders Peirce, and the essential distinction he draws between sign activity and "brute force":

It is important to understand what I mean by semiosis. All dynamical action, or action of brute force, physical or psychical, either takes place between two subjects (whether they react equally upon each other, or one is agent and the other patient, entirely or partially) or at any rate is

85 There is a grim possibility that ma'nā was in use by second/eighth-century inquisitors as a technical term for coerced confession. Cf. Scarry, Body in Pain, 46, for "the connection between two dreaded forms of exposure, open wounds and confession."

86 Meanings (2) and (3) are also correlated where Lisān art. $\sqrt{ }{ }^{\prime} n \bar{a}$ quotes Abū l-Haytham alRāzì (d. 276/889): "'Āñ is [said for] the submissive, the slave, and that which flows with

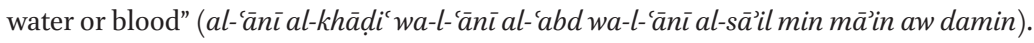


a resultant of such actions between pairs. But by "semiosis" I mean, on the contrary, an action, or influence, which is, or involves, a cooperation of three subjects, such as a sign, its object, and its interpretant, this trirelative influence not being in any way resolvable into action between pairs. ${ }^{87}$

The point here is not that violence and semiotics are exclusive domains. ${ }^{88} \mathrm{~A}$ beating can be the sign of worse violence to come. But the blow itself is present to body and mind directly, not represented by a third thing. The 'āni stands (or kneels) in a dynamic relation to his captors, a relation mediated by violence. Not through signs is a subject made aware of being captive, but from having the power to move around taken away.

Value on the other hand is robustly at issue in the man'n-verses, which depict in the end a scene of exchange: a large number of camels is given for the captive's life. The speaker is a man of wealth, and his herds are the fund from which his largesse is distributed. The captive's life is fungible, with a value relative to widows and other wretches. His relief on regaining his life (that faraj ba'd al-shidda) is not represented in the ma'na-verses, nor is his gratitude to the verses' speaker. The captive is not heard to pledge his life in return. We are shown the scene of captivity, and told of camels driven here and there. There is no monetary exchange: camels for a man's life, there is no third thing.

The signs at work in the captive's ma'na are immediate and embodied. Captivity is a matter of spatial fact, directly experienced — the kind of thing of which Husserl says that "we are consciously aware of it as given in its embodied form. We are not given an image or a sign in its place." 89 What is given to consciousness in its place is al-ma'na as the inward face of experience, whose outer face is the world of bodies caught in space. Meanings (1) and (2) of $\sqrt{ }{ }^{\prime} n w / y$ are two sides of the same seizure of attention, as Dewey and James have both said (above at n54). From this it is a small step to thinking of (2) and (1) as end-points, with phenomenological signs passing between them through the medium of the subject's body. From (2) to (3) the vector is even clearer: under duress, the subject becomes an object available for scrutiny, whose signs are given off whether or not the subject will.

The captive's state qua captive is a function of spatial relations. Some who are present at the scene are free to move around, and others are held in place.

\footnotetext{
87 Peirce, Pragmatism in Retrospect, 282.

88 As the example of "a piece of mould with a bullet-hole in it as sign of a shot" makes plain in Peirce, Logic as Semiotic, 104.

89 Husserl, Ideas, 123.
} 
Via (2) $\rightarrow(1)$, the sensible fact is available to the captive's consciousness, and via (2) $\rightarrow$ (3) it is manifest to his captors - "far from being a sign for something else, though to a certain extent a sign for itself." ${ }^{90}$ Only in this sense would $m a^{\prime} n \bar{a}$ in the verses be something signified, through self-ostentation of phenomena to consciousness. It is reality's experiential face, and, as Levinas says, "the face signifies itself." 11

Sign activity at the scene of the ma'na-verses is of this phenomenological kind. Abject and exposed to lethal forces "hovering" (hawāmī) about him, the captive is that figure haunting the pages of Totality and Infinity: "the body, indigent and naked" at the center of the perceptual world. ${ }^{92}$ In this regard, the very wonderful thing about the $m a^{\prime} n \bar{a}$-verses is that their speaker rises to the ethical demand emergent along vectors $(2) \rightarrow(3)$ and $(1) \rightarrow(3)$, as Levinas describes:

The face which the Other turns to me is not reabsorbed in a representation of the face. To hear his destitution which cries out for justice is not to represent an image to oneself, but is to posit oneself as responsible, both as more and as less than the being that presents itself in the face. Less, for the face summons me to my obligations and judges me. The being that presents himself in the face comes from a dimension of height, a dimension of transcendence whereby he can present himself as a stranger without opposing me as obstacle or enemy. More, for my position as $I$

Ibid., 146. All this is well summarized in MacCannell, Erving Goffman $\dagger, 24$ :

The phenomenological sign (Sinn = meaning) that we find in Husserl's writing is an effect on consciousness produced by a correlation between an object of consciousness "out there" and a particular thought, belief, or feeling. The sign in the phenomenological sense is dependent on the object of consciousness being present to consciousness, that is, it is dependent on appearance, perception and presence. The phenomenological sign is an instance of self-representation: i.e., it represents itself to consciousness. The semiotic sign is based on quite a different principle, namely the overcoming of absence, detachment, nonpresence: "a sign," according to Peirce's formulation, "represents something to someone"; not itself to consciousness, but something to someone. According to this second definition, the sign is not a meaning-effect that arises in consciousness as a result of a correlation between things, perceptions and thoughts; it is a pointer, indicator, marker, always directing consciousness beyond itself and beyond the immediate situation.

See additionally Jacques Fontanelle, La base perceptive de la sémiotique.

92 Ibid., 127:

The body naked and indigent is the very reverting, irreducible to a thought, of representation into life, of the subjectivity that represents into life which is sustained by these representations and lives of them; its indigence — its needs — affirm "exteriority" as non-constituted, prior to all affirmation. 
consists in being able to respond to this essential destitution of the Other, finding resources for myself. The Other who dominates me in his transcendence is thus the stranger, the widow, and the orphan, to whom I am obligated..$^{93}$

These altruistic values are not alien to the ma'na-verses in the least. On the contrary, they are a generic requirement: the charitable feat they describe is exactly what qualifies them as fakhr. A first-person speaker who cannot boast of relieving the destitution of the Other has no place in the $m a$ in $\bar{a}$-verses.

With all of this, we start to see why ma'na makes for an odd fit within theories of the sign. It is a phenomenological entity, secondarily adopted as a semiotic term. It is no conceptual analogue to the "signified" of Saussure's linguistic sign; Nașr Ḥāmid Abū Zayd in one place correlates it with "the link between the signifier and the signified" (al-'aläqa bayna l-ism wa-l-musammāa), which is apt - particularly if ma'na is thought of as a process of becomingmanifest. ${ }^{94}$ As "the exposure of inner content," "the presentation of an affair to consciousness," and even "the fact or circumstance of one's captivity," al-ma'nā is more of a connector than an end-point.

\subsection{Somatics of Meaning}

In the latent phenomenological paradigm of al-ma'na $\bar{a}$, the body is a medium. It is the site of the duress that brings affairs to consciousness for the subject and the subject's observers alike. Captivity need not be a literal fact; it can be a metaphor for any engrossing situation (hence captivation), as well as a synecdoche for other positions a subject might occupy, abject or otherwise. The 'ān $\bar{\imath}$ of my three-part paradigm is understood to be "caught" in a given situation as the Latinate subject is understood to be "thrown" into one. The speaker of the $m a^{\prime} n \bar{a}$-verses may be said to have a ma'nā too - his "way of being caught" in social space - that is most unlike the captive's ma'nā.

Figurative drift like this no doubt contributes to $m a^{\text {'n}} n \bar{a}^{\prime}$ s wide applicability. My hypothesis requires it, because I do not contend that actual captivity is latent every time the word is used. My modest contention is rather that bearing up under the stress of captivity works as a metaphor and a synecdoche for experience generally. What is latent in al-ma'nā is a certain positionality, or a modification of dynamic spatial relations that brings something into view. Some such figurativity may, I trust, be observed in the conceptual vocabulary of any language, as affect theorist Denise Riley writes: "In the frequent

93 Ibid., 215 (emphasis mine).

94 Abū Zayd, al-Ittijāh al-'aqlì, 84 . 
spatiality of conceptual thought, a fundamental metaphoricity of place and depth is embedded (as in those very words residual, fundamental, embedded)" posing then a question that may have crossed my reader's mind: "But is such an observation merely a rebirth of old fevers of the excessively literalized etymological radicalism which gripped many wild nineteenth-century linguists?"95

The question hits home. There is in fact something untimely about a philological approach to the history of ideas, despite some enduring landmarks. ${ }^{96}$ To this I can only say that if a detailed etymological study of al-ma'nā had been produced in the nineteenth century, or in 1968 or at any other point of time, the present article would not have had to be written. My dependence on poetic evidence is part of what makes it a "throwback" - not to the nineteenth century CE, but to the second, third and fourth AH. All of my source materials and some of my method owe to the philologists of the Abbasid period - Basran and Kufan alike - who argued over this same evidence while preserving it in recitation and in manuscript. Unavoidably, this article will appear in the character of an homage to the classical authorities whom Muhsin Mahdi says "have as it were set themselves up as a screen between [the gender-masculine student of Classical Arabic philology] and the raw material that he intends to investigate." 97

But etymology is not destiny. Without disavowing the figurative extensions that philology uncovers, I don't essentialize them, nor grant them primacy over synchronic technical usage. I do consider them vital for taking a comparativist approach to mental categories as these are construed in language - an approach that "listens," as John A. Lucy puts it, "closely to what the language forms volunteer, pursuing various structured, crosscutting patterns of meaning and attempting to make sense of how the world must appear to someone using such categories," arriving ideally at "the characterization of the distinctive way a language interprets the world." 98

Patterns of meaning are one thing, though, and representations of meaning another. My question here was one of mimesis: how is it that meaning itself might be pictured as a function of dynamic corporeal relations, as Ibn Fāris suggests that ma'na could be? The short answer is that language always represents structures of thought as metaphorical elaborations on corporeality. How

95 Riley, Impersonal Passion, 51.

96 Foucault, Order of Things, 298: "The first book of Das Kapital is an exegesis of 'value'; all Nietzsche is an exegesis of a few Greek words," etc.

97 Mahdi, review of Fleisch, Traité de philologie arabe, 290.

98 Lucy, Linguistic Relativity, 296. 
to think of meaning outside of such representations is the harder question or series of questions, as Denise Riley goes on to ask:

Then if the names of the structures of thought are themselves metaphorical, isn't the very idea of there being any "structure" to thought itself also figurative? Yet if so, what would constitute the nonfigurative here?.... Concepts, often figurative, are mapped onto each other, working in tandem within 'the unity of the verbally constituted consciousness,' as Vološinov put it. ${ }^{99}$ Yet what if the very concepts which ground this overlapped consciousness, those of an external world and an internal world, begin themselves to ring strangely in our ears; what if all this interiority and its opposing exteriority are also themselves metaphorical? And then the ensuing question relentlessly becomes: metaphorical to what?100

Thinking outside of such metaphors is not only an interesting thought experiment, but an imperative of philosophy of mind. Even so, it is no easy thing to sail past the pillars of interiority and exteriority — least of all where outward exposure of inner content is one of $m a^{\prime} n \bar{a}^{\prime}$ s master metaphors.

In this article it was important to leave aside the specific terminological consequences of $m a^{\prime} n \bar{a}$ 's derivation, beyond noting the lexical and morphological preconditions for its pluripotentiality. My purpose here was to attend to drift, and for this the best evidence comes from poetry. My findings are that ma'nä's somatic and phenomenological metaphoricities were not "dead" in the first centuries of Islam but still-living tropes, accessible now through Kitāb al-'Ayn, $a l-S a \bar{a} h i b \bar{i}$, and the work of early poets (including the unknown master of the $m a^{\prime} n \bar{a}$-verses) who enlisted its root verb-complex in wordplay.

I close with a poetic instance of ma'na by one of the last poets to be considered early. ${ }^{101}$ Ru'ba b. al-'Ajjāj (d. 145/762) was simultaneously a poet of great traditionalism and great inventive skill, who (along with his father al-'Ajjāj, d. 97/715) brought the monorhymed rajaz mashtūr form to qașïda-like heights. In one rahill passage describing a night-journey, the poet boasts of the speed and surefootedness of his Mahrī camels:

\footnotetext{
99 A reference to Vološinov, Marxism and the Philosophy of Language, 15.

100 Riley, Impersonal Passion, 51.

101 Baalbaki, Historic Relevance, 104.
} 


\begin{abstract}
Wa-in khaṣāṣu laylihinna staddā șadadna 'an 'irninihi aw șaddā 'anhā wa-ta'rawrā sihāban jurdā idhā tahāwī l-qarabijrahaddā ka’anna taḥtì dhà shiyātin fardā bādara laylan wa-shamālan șardā arțā wa-ahqqāfan yadhudna l-bardā yandū l-mațāyā anaqan wa-wajdā naḍaka 'an șadri l-yamānì l-ghimdā tațrudu dhamman wa-tudannī ḥamdā ta'mì ma'ānìhà l-lughāma l-ja'dā. Là ta'du aqwāmun ilayya l-qașdā abdaw mina l-ghayzi wujūhan rubdā ${ }^{102}$
\end{abstract}

With no gap open in the [darkness of the] night, they avoid its pointy stones, or [its pointy stones] avoid them, as they are ridden barefoot through the desert bare and sere. When our emaciating night-journey goes on and on without a water-stop, it is as if a matchless [wild bull] were underneath me, one with striped legs, dashing through the night and the North wind's chill, [seeking] the scrub-brush and sand-hills that fend off the cold, outstripping [other men's] mounts in their paces [quickly] as you strip the scabbard from a Yemeni sword. Repulsing blame and attracting praise, they cast their $\boldsymbol{m a} \boldsymbol{a} \boldsymbol{a} n \bar{\imath} \bar{\imath}$ as thickly-clotted spittle.

- May they not intend hostility toward me, those folks who advertise their ire on ashen faces!

It is impossible to fault Ahlwardt here (and Key after him) for translating ma'āni as the camels' "content" (ihr Inhalt). ${ }^{103}$ What comes to light as cast spittle obviously comes from within, much as the water-skin in al-Mutanakhkhil's verse exudes $\left(\operatorname{ta}^{\prime} n \bar{u}\right)$ its contents through a puncture. The verb here, 'ama $t a^{\prime} m \bar{\imath}$, denotes abundant emission (in another of Ru'ba's poems it is used it of the Nile's flow), and is a literal word for camel expectoration, too. ${ }^{104}$ All this spitting may

\footnotetext{
102 Ru'ba, Sammlungen, III.42 (no. 17, verses 16-28).

103 Ru’ba, Dīwān des Reḡezdichters, 66: "Abweisend Tadel und anziehend Lob: / Ihr Inhalt sprudelt und wirft krausen Schaum aus."

104 Ru’ba, Sammlungen, III.96 (no. 35, verse 39).
} 
put the hearer in mind of al-lafz, which, in addition to being the "utterance" that communicates a ma'na to a hearer, is a verbal noun for spitting. ${ }^{105}$ The camels' ma'ān sions": instances in either case of "coming to light," engaging phenomenological meaning (3) of $\sqrt{ }{ }^{\prime} n w / y .{ }^{106}$ Their being cast as spittle weds abstract ma'āni to concrete lughām - the kind of metaphor that al-Jurjānī called "the pure type" (al-șamìm al-khäliș min al-isticära): "not the same as the one existing between the flight of a bird and the running of the horse," but one that spans two realms of existence, as when lucid argument is compared to light. ${ }^{107}$

This much tells us that inner content streams forth in abundance, but not what that content is. Affect, thought, feelings? Quite naturally. In rahïl poetry, the emotional lives of riding camels (often filtered through long and pathosladen similes that compare the camel to some put-upon beast of the wild) are a regular concern. These camels have traveled far without water, which determines their intentions in the grueling matter. Then, in the next line, the fact of intention is echoed and reinforced in the optative lä ta'du aqwämun ilayya l-qașdā: "May they not intend hostility toward me ..." Even if qașd is no decisive key to the meanings of the previous verse, there are abundant grounds for interpreting the camels' ma'anni as intentional entities, in accordance with the root verb's psychological meaning (1).

A metapoetic reading also presents itself. In a poem that up to this point has spoken of little but the speed and indefatigability of the poet's camels - in which their merits are the poem's theme - the ma'ān of the camels and the ma'āni of the poem are the selfsame ma'änī. In this sense, the camels' ma'äni are occasions for description and praise, and something close to proofs of worth: merits and exploits, cast off as abundantly as spittle.

Meanings (1) and (3) of $\sqrt{ }{ }^{\prime} n w / y$ are therefore coefficient in the polysemy of Ru'ba's ma'ānī. The captivity of meaning (2), meanwhile, seems not to be in play. It might yet be structurally implicit in the metapoetic reading, insofar as the camels' night-journey puts their endurance to a test - no immobilizing captivity, but a mobile one, something like a forced march. Ma'ānī as "exploits" would be the ostensive consequence of meaning (2), which is ma'na as "trial." When their worth is tested, the camels prove it, bearing up under their duress and flowing $\left(\operatorname{ta}^{\mathrm{c}} \mathrm{m} \bar{\imath}\right)$ with distinguishing achievements.

105 Al-Jāhị (Hayawān, II 152) reports that a young rooster is called lāfiza because it picks up seeds and spits them before the hen.

106 The commentator Muhammad b. Habīb (d. 245/860), so crucial for understanding Ru'ba's poetry, has nothing to say about ma'āni’s meaning here (Yale MS Landberg 742, fol. 438b).

107 Abu Deeb, Al-Jurjānī’s Classification, 70-71, quoting al-Jurjānī, Asrār, 6o-61. 
The question of meaning is all-ongoing. One doesn't raise it so much as tune it in. As a function of duress, it is well known. It is pathos and affect, passion and affection, undergone and manifested by the subject in one ergative wave. It not only determines intention, it is intention. It is contingent being, circumstantial, and at that there is no end to what might be said about meaning, but $m a^{\prime} n \bar{a}$ is a realistic way of saying it.

\section{References}

\section{Primary Sources}

Al-'Askarī, Abū Hilāl, Kitāb al-Furūq, ed. by Aḥmad Salīm al-Ḥimṣī, Tripoli (Lebanon): J. Briss, 1994

Al-Azharī, Abū Manșūr, Tahdhīb al-lugha, ed. by 'Abd al-Salām Muhammad Hārūn et al., 15 vols., Cairo: al-Mu’assasa al-Mișriyya al-'Āmma li-l-Ta'līf wa-l-Anbā' wa-lNashr, 1964-1967

De Condillac, Étienne Bonnot, Essay on the Origin of Human Knowledge, trans. by Hans Aarsleff, Cambridge: Cambridge Univ. Press, 2001

Al-Farrā’', Yahyā b. Ziyād, Ma'ānī al-Qur'ān, 3rd printing, 3 vols., Beirut: 'Alam al-Kutub, 1983

Al-Fayyūmī, Aḥmad b. Muḥammad, al-Mișbāh al-munīr, Beirut: Maktabat Lubnān, 1987

Ibn al-Anbārī, Abū Bakr Muhammad b. al-Qāsim, al-Zāhir fì ma'ānī kalimāt al-nās, ed. by Ḥātim Ṣālị al-Ḍāmin, 2 vols., Baghdad: Dār al-Shu'ūn al-Thaqāfiyya al-'Āmma 1987-1989

Ibn al-Anbārī, Abū Bakr Muḥammad b. al-Qāsim, Kitāb al-Aḍdād, ed. by Muhammad Abū l-Faḍl Ibrāhīm. Kuwait: Dāirat al-Maṭbūāàt wa- l-Nashr, 1960

Ibn 'Asākir, Abū l-Qāsim 'Alī b. al-Ḥasan, Tārīkh madīnat Dimashq, ed. by 'Umar b. Gharāma al-'Amrawī, 80 vols., Beirut: Dār al-Fikr, 1995

Ibn Fāris, Abū l-Ḥusayn Aḥmad, Mújam Maqāyīs al-lugha, ed. by 'Abd al-Salām Muhammad Hārūn, end printing, 6 vols., Cairo: Maktabat al-Bābī l-Halabī, 1971

Ibn Fāris, Abū l-Ḥusayn Aḥmad, al-Ṣahhibì fífigh al-lugha al-'arabiyya wa-masā̉ilihā wasunan al-'arabfí kalāmihā, ed. by Aḥmad Ḥasan Basaj, znd ed., Beirut: Dār al-Kutub al-Ilmiyya, 2007

Ibn Fāris, Abū l-Ḥusayn Aḥmad, Mujmal al-lugha, ed. by Hādī Ḥasan Ḥammūdī, 5 vols., Kuwait: Machad al-Makhțūțāt al-Arabiyya, 1985

Ibn al-Jazarī, Ghāyat al-nihāya fí țabaqūt al-qurrā', ed. by Gotthelf Bergsträsser and Otto Pretzl, 3 vols., Cairo: Maktabat al-Khanjī, 1932-1935

Ibn Jinnī, Abū l-Fatḥ 'Uthmān, al-Khașā̉iș, ed. by Muḥammad 'Alī al-Najjār, 3 vols., Cairo: Mațba'at Dār al-Kutub al-Mișriyyah, 1952-1956 
Ibn Jinnī, Abū l-Fatḥ 'Uthmān, al-Muhtasab fì tabyīn wujūh shawadhdh al-qirāāât wal-ị̣ạh 'anhā, ed. by Muḥammad 'Abd al-Qādir 'Ațā', 2 vols., Beirut: Dār al-Kutub al'Ilmiyya, 1998

Ibn Khālawayh, al-Ḥusayn b. Aḥmad, Mukhtașar fi shawādhdh al-Qur'ān, ed. by Gotthelf Bergsträsser, Leipzig: Nashriyyāt al-Islāmiyyat li-Jamī'at al-Mustashriqīn al-Almāniyya, 1934

Ibn Mākūlā, 'Alī b. Hibat Allāh, al-Ikmāl fì raf' al-irtiyāb, ed. by Nāyif al-'Abbās, 7 vols., Beirut: Muḥammad Amīn Damaj, 197-?

Ibn Manẓūr, Jamāl al-Dīn Muḥammad b. Mukarram, Lisān al-'arab, ed. by 'Āmir Aḥmad Ḥaydar and 'Abd al-Mun'im Khalīl Ibrāhīm, 10 vols., Beirut: Dār al-Kutub al-'Ilmiyya, 2005

Ibn al-Nadīm, Abū l-Faraj Muḥammad, al-Fihrist, ed. by Yūsuf 'Alī Ṭawīl and Aḥmad Shams al-Dīn, 1 vol., Beirut: Dār al-Kutub al-'Ilmiyya, 2002

Ibn Qutayba, 'Abdallāh b. Muslim, Kitāb al-Ma'ānì al-kabīr fì abyāt al-ma'ānī, [ed. by Fritz Krenkow], 3 vols., Beirut: Dār al-Kutub al-'Ilmiyya, 1984

Al-Iṣfahānī, Abū l-Faraj, Kitāb al-Aghānī, ed. by Iḥsān 'Abbās et al., 3rd printing, 25 vols., Beirut: Dār Șādir, 2008

Al-Iṣfahānī, Abū Nu'aym, Hilyat al-awliyāà wa-țabaqāt al-aşfiyā', 10 vols., [Cairo]: Maktabat al-Khānjī, 1932-1938

Al-Jāḥiz, 'Amr b. Baḥr, al-Bayān wa-l-tabyīn, ed. by 'Abd al-Salām Muḥammad Hārūn, 4 vols., Cairo and Beirut: Maktabat al-Khānjī/Maktabat al-Hilāl, 1968

Al-Jāḥiẓ, 'Amr b. Baḥr, Kitāb al-Hayawān, ed. by 'Abd al-Salām Muhammad Hārūn, 7 vols., Cairo: Maktabat al- Bābī l-Ḥalabī, 1938-1965

Jāmī, Nūr al-Dīn 'Abd al-Raḥmān, al-Fawāid al-ḍiyāiyya. Istanbul: Kırımlı Abdullah Efendi Matbaası, 1896

Al-Jawharī, Ismāềl b. Ḥammād, al-Ṣihạhh, ed. by Aḥmad 'Abd al-Ghafūr 'Aț̣āā, 6 vols. in 7, Cairo: Dār al-Kitāb al-'Arabī bi-Mișr, [1957]

Al-Jurjān̄̄, 'Abd al-Qāhir, Asrār al-balāgha, ed. by Helmut Ritter, Istanbul: Government Press, 1954

Al-Khafājī, Aḥmad b. Muḥammad, Hāshiyat al-Shihāb, al-musammā bi-Ināyat al-qāḍ̄ wa- kifāyat al-rāḍ̄ 'alā Tafsìr al-Bayḍwā̄, 8 vols., Bulaq: Dār al-Ṭibā'a al-Āmira, 1867 Al-Khalīl b. Aḥmad, Kitāb al-'Ayn, 1 vol., Beirut: Dār Ihyyā' al-Turāth al-'Arab̄̄, 2001

Al-Khațīb, 'Abd al-Lațîf Muhammad, Mu jam al-qirā’àt, Cairo: Dār Sa‘d al-Dīn li-l-Ṭibāaca wa-l- Nashr wa-l-Tawzī', 2002

Al-Lughawī, Abū l-Ṭayyib, Kitāb al-Aḍdād fi kalām al-'arab, ed. by 'Izzat Ḥasan, Damascus: Maṭbū'āt al-Majma' al-'Ilmī al-'Arabī, 1963

Al-Lughawī, Abū l-Ṭayyib, Marātib al-naḥwiyyīn, ed. by Muḥammad Abū l-Faḍl Ibrāhīm, Cairo: Maktabat Nahḍat Miṣr, 1955

Mendelssohn, Moses, Morning Hours, trans. by Daniel O. Dahlstrom and Corey Dyck. Dordrecht: Springer, 2011 
Al-Qifțī, Jamāl al-Dīn Abū l-Ḥasan 'Alī, Inbāh al-ruwāt 'alā anbāh al-nuhāàt, ed. by Muḥammad Abū l-Faḍl Ibrāhīm, 4 vols., Cairo: Dār al-Fikr al-Arabī, 1986

Al-Ṣabbān al-Miṣrī, Abū l-'Arfān Muhammad b. 'Alī, Risāla fì l-maṣdar al-mīmī wa-ismay al-makān wa-l-zamān, in: Muhammad 'Abd al-Salām Muhammad (ed.), Rasāìl fìl-naḥw wa-l-ṣarf, Cairo: al-Āfāq al-'Arabiyya, 2011, 117-128

Al-Sijistānī, Abū Ḥātim, Kitāb al-Aḍdād, in: August Haffner (ed.), Thalāthat kutub al-

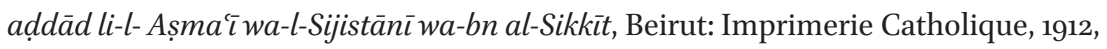
71-162

Vico, Giambattista, New Science, trans. by David Marsh, New York: Penguin, 1999

Yāqūt al-Ḥamawī, Mu'jam al-udabā', ed. by Iḥsān 'Abbās, 7 vols., Beirut: Dār al-Gharb al-Islāmī, 1993

Al-Zubaydī, Muḥammad b. Muḥammad Murtaḍā, Tāj al-'arūs, 10 vols., Benghazi: Dār Lībiyā, 1966

\section{Poetry Collections}

'Adī b. Zayd al-'Ibādī, Dōwān 'Adì, ed. by Muhammad Jabbār al-Mu'aybid, Baghdad: Wizārat al-Thaqāfa wa-l-Irshād, 1965

Al-A'shā al-Kabīr, Maymūn b. Qays, Dīwān al-A'shāa, ed. by Kāmil Sulaymān, Beirut: Dār al- Kitāb al-Lubnānī, n.d.

Al-Ḍabbī, al-Mufaḍḍal, al-Mufaḍdaliyyāt, ed. by Aḥmad Muḥammad Shākir and 'Abd al-Salām Muḥammad Hārūn, Cairo: Dār al-Ma'ārif bi-Miṣr, $195^{2}$

Dhū l-Rumma, Dīwān Dhī l-Rumma Ghaylān b. 'Uqba al-'Adawì al-mutawaffā fì sana 117 H.; Sharh al-Imām Abī Nașr Aḥmad b. Hātim al-Bāhilī, șāḥib al-Așmacī; Riwāyat al-Imām Abī l-'Abbās Tha'ab, ed. by 'Abd al-Quddūs Abū Șāliḥ, 3 vols., Damascus: Majma' al- Lugha al-'Arabiyya, 1972-73; repr. Beirut: Mu’assasat al-Īmān, 1982

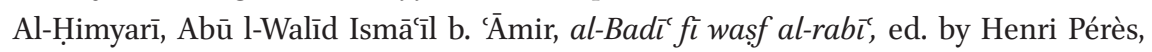
Cairo: Maktabat al-Thaqāfa al-Dīniyya, 2002

Imru' al-Qays, Dōwān Imri' al-Qays, ed. by Muḥammad Abū l-Faḍl Ibrāhīm, Cairo: Dār al- Ma'ārif, 1964

Al-Rā'ī al-Numayrī, Dōwān al-Rā'č al-Numayrī, ed. by Reinhard Weipert. Wiesbaden: Franz Steiner Verlag, 1980

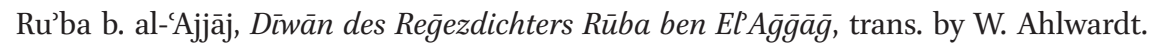
Berlin: Verlag von Reuther \& Reichard, 1904

Ru'ba b. al-'Ajjāj, Sammlungen alter arabischer Dichter III: der Dīwān des Reḡezdichters Rüba ben El A $\bar{g} \bar{g} \bar{a} \bar{g}$, ed. by W. Ahlwardt, Berlin: Verlag von Reuther \& Reichard, 1903

Al-Sukkarī, Abū Sa'īd. Sharh ashāar al-Hudhaliyīn, ed. by 'Abd al-Sattār Aḥmad Farrāj and Maḥmūd Muḥammad Shākir, 3 vols., Cairo: Maktabat Dār al-'Urūba, 1963-1965 Al-Sulayk al-Sulaka, Dīwān al-Sulayk, ed. by Sa'dī al-Ḍināwī, Beirut: Dār al-Kitāb al'Arabī, 1994 
Tha'lab, Sharh Shi'r Zuhayr, ed. by Fakhr al-Dīn Qabāwa, 3rd printing, Damascus: Maktabat Hārūn al-Rashīd li-l-Tawzī‘ , 2008

[al-Ṭūsi, 'Alī b. 'Abd Allāh,] Sharh Dīwān Labīd b. Rabī'a al-Āmirì, ed. by Iḥsān 'Abbās, Kuwait: Wizārat al-Irshād wa-l-Anbā', 1962

'Umar b. Abī Rabī‘a, Sharh Dīwān 'Umar, ed. by Muhammad Muhyī l-Dīn 'Abd alHamīd, 2nd printing, [Cairo]: Mațba'at al-Sa'āda, 1960

Umayya b. Abī l-Ṣalt, Dīwān Umayya, ed. by Sajī̌ Jamīl al-Jubaylī, Beirut: Dār Șādir, 1998

\section{Secondary Sources}

Abu Deeb, Kamal, Al-Jurjānīs Classification of Isticāra, in: JAL 2/1 (1971), 48-75

Abū Zayd, Nașr Ḥāmid, al-Ittijāh al-'aqlì fì l-tafsīr, Beirut: Dār at-Tanwīr li-l-Ṭibā'a wa-l-Nashr, 1982

Anthony, Sean, The Domestic Origins of Imprisonment: An Inquiry into an Early Islamic Institution, in: JAOS 129/4 (2009), 571-596

Aro, Jussi, Der Mașdar al-mīmı̄ und seine Funktion im Arabischen, in: Studia Orientalia 28/11 (1964), 3-19

Baalbaki, Ramzi, Arab Grammatical Controversies and the Extant Sources of the Second and Third Centuries A.H., in: Wadād al-Qāḍī (ed.), Studia Arabica et Islamica: Festschrift for Iḥsān 'Abbās, Beirut: AU B Press, 1981, 1-26

Baalbaki, Ramzi, The Arabic Lexicographical Tradition: From the 2nd/8th to the 12th/18th century, Leiden: Brill, 2014

Baalbaki, Ramzi, The Historic Relevance of Poetry in the Arab Grammatical Tradition, in: Baalbaki et al. (eds.), Poetry and History, Beirut: Au в Press, 2011, 95-120

Black, Deborah L., Intentionality in Medieval Arabic Philosophy, in: Quaestio 10 (2010), $65-81$

Bravmann, M.M., Studies in Semitic Philology, Leiden: Brill, 1977

Carter, Michael G., The Struggle for Authority: A Re-examination of the Bașran and Kūfan Debate, in: Lutz Edzard and Mohammed Nekroumi (eds.), Tradition and Innovation, Wiesbaden: Harrassowitz, 1999, 55-70

Crone, Patricia, Roman, Provincial and Islamic Law, Cambridge: Cambridge Univ. Press, 1987

Davidse, Kristin, Transitivity/Ergativity: The Janus-headed Grammar of Actions and Events, in: Martin Davies and Louise Ravelli (eds.), Advances in Systemic Linguistics: Recent Theory and Practice, London: Pinter, 1992, 105-135

Dewey, John, Does Reality Possess Practical Character? in: Jo Ann Boydston (ed.), The Middle Works, vol. 4: 1907-19o9, Carbondale: Southern Illinois Univ. Presss, 1977, 125-142

Fontanelle, Jacques, La base perceptive de la sémiotique, in: Harjeet Singh Gill and Giovanni Manetti (eds.), Signs and Signification, New Delhi: Bahri Publications, 1999, I, 257-278 
Forand, Paul G., The Relation of the Slave and the Client to the Master or Patron in Medieval Islam, in: International Journal of Middle East Studies 2/1 (1971), 59-66

Foucault, Michel, The Order of Things [trans. by Alan Sheridan], New York: Vintage Books, 1994

Frank, Richard M., Al-ma'nà: Some Reflections on the Technical Meanings of the Term in the Kalâm and its Use in the Physics of Mu'ammar, in: JAOS 87/3 (1967), 248-259

Frank, Richard M., Meanings are Spoken of in Many Ways: The Earlier Arab Grammarians, in: Muséon 94/3-4 (1981), 259-319

Frank, Richard M., Yā Kalām, in: Dimitri Gutas (ed.), Philosophy, Theology and Mysticism in Medieval Islam, Aldershot, U.K./Burlington, VT: Ashgate Variorum, 2005, 1-10

Genette, Gérard, Mimologics, trans. by Thaïs E. Morgan, Lincoln: Univ. of Nebraska Press, 1995

Good, Robert M., Exodus 32:18, in: John H. Marks and Robert M. Good (eds.), Love \& Death in the Ancient Near East: Essays in Honor of Marvin H. Pope, Guilford, CT: Four Quarters, 1987, 137-142

Gyekye, Kwame, The Terms 'Prima Intentio' and 'Secunda Intentio' in Arabic Logic, in: Speculum 46/1 (1971), 32-38

Hämeen-Anttila, Jaakko, Al-Așma'̄ì, Early Arabic Lexicography and Kutub al-Farq, in: Zeitschrift für Geschichte der Arabisch-Islamischen Wissenschaften 16 (2004/05), $141-148$

Hämeen-Anttila, Jaakko, Review of Zammit, Martin R.: A Comparative Lexical Study of Qur'ānic Arabic, in: Wiener Zeitschrift für die Kunde des Morgenlandes 93 (2003), 294-296

Haq, Syed Nomanul, Names, Natures and Things: The Alchemist Jābir ibn Hayyān and his Kitāb al-Ahjār (Book of Stones), Dordrecht: Springer, 1994

Heinrichs, Wolfhart, On the Genesis of the Haqîqa-Majâz Dichotomy, in: Studia Islamica 59 (1984), 111-140

Horten, Max, Was bedeutet ma'nā als philosophischer Terminus? in: Zeitschrift der Deutschen Morgenländischen Gesellschaft 64 (1910), 391-396

Husserl, Edmund, Ideas: General Introduction to Pure Phenomenology, trans. by W.R. Boyce Gibson, New York: Collier Books, 1962

James, William, The Principles of Psychology, 2 vols, New York: Dover, 1950

Justice, David, The Semantics of Form in Arabic, Amsterdam: John Benjamins, 1987

Key, Alexander, Language Between God and the Poets: Ma'nā in the Eleventh Century, Berkeley: University of California Press, 2018

Khalfallah, Nejmeddine, La théorie du ma'nā d'après 'Abd al-Qāhir al-Ǧurǧāñ̄, Paris: L'Harmattan, 2014

Kouloughli, Djamel Eddine, Ma'nā, in:Encyclopedia of Arabic Language and Linguistics, 5 vols., Leiden: Brill, 2008, III, 159-164 
Lane, Edward William, Arabic-English Lexicon, 8 vols. in 2, Cambridge: Islamic Texts Society, 1984

Larkin, Margaret. The Theology of Meaning: 'Abd al-Qāhir al-Jurjānì's Theory of Discourse, New Haven: American Oriental Society, 1995

Larsen, David, Towards a reconstruction of Abū Naṣr al-Bāhilī’s Kitāb Abyāt al-macānī (forthcoming)

Levinas, Emmanuel, Totality and Infinity, trans. by Alphonso Lingis, The Hague: Martinus Nijhoff Publishers, 1979

De Libera, Alain, Intention, in: Barbara Cassin (ed.), Emily Apter et al. (eds. and trans.), Dictionary of Untranslatables, Princeton: Princeton Univ. Press, 2014, 500-511

Lucy, John A., Linguistic Relativity, in: Annual Review of Anthropology 26 (1997), 291-312 MacCannell, Dean, Erving Goffman† (1922-1982), in: Semiotica 45/1-2 (1983), 1-33

Mahdi, Muhsin, Review of Fleisch, Henri, Traité de philologie arabe, Vol. I, in: jnes 23/4 (1964), 289-290

Makujina, John, Additional Considerations for Determining the Meaning of 'anôt and 'annôt in Exod. XXXII 18, in: Vetus Testamentum 55/1 (2005), 39-46

Al-Nāqūrī, Idrīs, al-Muștalaḥ al-naqdī fì «Naqd al-shi'r», Casablanca: Dār al-Nashr alMaghribiyya, 1982

Nida, Eugene, Exploring Semantic Structures, Munich: Wilhelm Fink, 1975

Orfali, Bilal, A Sketch Map of Arabic Poetry Anthologies up to the Fall of Baghdad, in: JAL 43 (2012), 29-59

Peirce, Charles Sanders, Logic as Semiotic: The Theory of Signs; and Pragmatism in Retrospect: A Last Formulation, in: Justus Buchler (ed.), Philosophical Writings of Peirce, New York: Dover, 1955, 98-119 and 269-289

Riley, Denise, Impersonal Passion: Language as Affect, Durham: Duke Univ. Press, 2005

Roman, André, Sur la constitution des unités de la langue arabe, in: Travaux 1: Les parties du discours, Aix-en-Provence: Cercle Linguistique d'Aix-en-Provence, 1983, $113-144$

Sabra, A.I. (ed. and trans.), The Optics of Ibn al-Haytham: Books I-III On Direct Vision, 2 vols., London: Warburg Institute/Univ. of London, 1989

Scarry, Elaine, The Body in Pain: The Making and Unmaking of the World, New York: Oxford Univ. Press, 1995

Schoeler, Gregor, The Genesis of Literature in Islam, trans. by Shawkat Toorawa, Edinburgh: Edinburgh Univ. Press, 2009

Scott, Alan K., Accounting for the Semantic Extension of Derived Action Nouns, in: Journal of Linguistics 46/3 (2010), 711-734

Thubaytī, Jarīdī Salīm al-Manșūrī, Abyāt al-ma ānī haattā nihāyat al-qarn al-thālith alHijrī, Ph.D. dissertation, Jāmi'at Umm al-Qurā, 1989

Toorawa, Shawkat, Ibn Abī Țāhir Tayfur and Arabic Writerly Culture, New York: Routledge, 2005 
Versteegh, C.H.M., Ma'nā (A.), in: Encyclopaedia of Islam, Second Edition, 13 vols., Leiden: Brill, 1954-2005, VI, 346

Vološinov, V.N., Marxism and the Philosophy of Language, trans. by Ladislav Matejka and I.R. Titunik, Cambridge: Harvard Univ. Press, 1986

Weil, Gotthold, Die Grammatischen Schulen von Kufa und Basra, Leiden: Brill, 1913

Wolfson, Harry A., Mu'ammar's Theory of Ma'nā, in: George Makdisi (ed.), Arabic and Islamic Studies in Honor of Hamilton A. R. Gibb, Leiden: Brill, 1965, 671-688

Wolfson, Harry A., The Philosophy of the Kalam, Cambridge: Harvard Univ. Press, 1976

Wright, W[illiam], A Grammar of the Arabic Language, 3rd ed., 2 vols. in 1, Cambridge: Cambridge Univ. Press, 1967

Ya'qūb, Emile Badī', al-Mujam al-mufașṣal fı̀ shawāhid al-lugha al-'arabiyya, Beirut: Dār al-Kutub al-'Ilmiyya, 1996 